\title{
EFFECTS OF TEMPERATURE AND ACTIVITY ON AEROBIC AND ANAEROBIC METABOLISM AND HEART RATE IN THE TURTLES PSEUDEMYS SCRIPTA AND TERRAPENE ORNATA
}

\author{
ROBERT E. GATTEN, JR.* \\ Department of Zoology, The University of Michigan, Ann Arbor, Michigan 48104, U.S.A.
}

(Received 16 fuly 1973)

\begin{abstract}
The aerobic metabolic scope for activity is 1.75 times greater in the active, aquatic, red-eared turtle, Pseudemys scripta, than in the more sluggish, terrestrial, ornate box turtle, Terrapene ornata, at their common preferred body temperature of $30^{\circ} \mathrm{C}$.

2. Oxygen consumption increases eight- to thirtyfold during activity.

3. Both heart rate and oxygen pulse rise with an increase in body temperature and with exercise.

4. At $30^{\circ} \mathrm{C}$ glycolysis supplies $60-75$ per cent of the energy available during a burst of activity.

5. At $30^{\circ} \mathrm{C}$ total metabolic scope for activity is 1.14 times greater in P. scripta than in $T$. ornata.
\end{abstract}

\section{INTRODUCTION}

REPTILES, in general, and turtles, in particular, have been regarded since Antiquity as passive, sluggish and inefficient creatures. In view of the extent to which the classical views of the limited functional capabilities of lizards and snakes have been discredited by recent research and in light of the striking morphological differences between chelonians and other reptiles, it appeared of interest to investigate various aspects of the physiological performance of turtles. One such measure of functional capability is the aerobic metabolic scope for activity (Fry, 1947), the degree to which an animal can make energy available for activity without incurring an oxygen debt. Whereas metabolic scope has been measured in several squamates (see Bennett \& Dawson, 1974 for review), no systematic determinations of metabolic scope in chelonians at various levels of body temperature have been made previously. Since aerobic metabolism must be supported by oxygen transport, it was of interest to measure heart rate simultaneously with metabolic rate in order to provide information on the response of the circulatory system to changes in body temperature and activity level.

Anaerobic metabolism is known to serve two distinct functions in reptiles. Lizards employ glycolysis in providing the majority of the energy available to

* Present address: Department of Biology, The College of Wooster, Wooster, Ohio 44691, U.S.A. 
them in short bursts of activity (Bennett \& Dawson, 1972; Bennett \& Licht, 1972). Turtles rely on anaerobiosis as the chief source of energy during long periods of diving (Belkin, 1961; Berkson, 1966). Whether turtles can make use of their extraordinary glycolytic capability during brief periods of maximal exercise has not been investigated previously and was therefore examined here. Knowledge of the responsc of acrobic and anaerobic metabolism to changes in temperature and activity may thus assist in understanding the success of this evolutionarily conservative but successful group of reptiles.

Two species of the family Emydidae, the aquatic red-eared turtle, Pseudemys scripta elegans, and the terrestrial ornate box turtle, Terrapene ornata ornata, were chosen for this study. Red-eared turtles are considered to be quick, active and alert (Cahn, 1937) and their activity persists over a wide range of body temperatures and throughout most months of the year in the north-central United States (Cagle, 1946). Ornate box turtles appear to be more sluggish than red-eared turtles and low temperature seems to be an important factor limiting their distribution (Legler, 1960). Ornate box turtles can move away from danger with remarkable rapidity, but their common method of defense is to remain motionless and withdraw into their shell (Legler, 1960). Dissimilarity in the physiological capabilities of these two species may thus reflect the differences in their physical structure, their habits and the environments which they occupy.

\section{MATERIALS AND METHODS}

\section{Experimental animals}

The Pseudemys scripta elegans used in this study were obtained from a commercial dealer (Mogul-Ed, Oshkosh, Wisconsin). Specimens of Terrapene ornata ornata, collected in Chase and Douglas Co., Kansas, were generously provided by Mr. Robert K. Beatson. All animals were kept in a room with large windows along one wall. Fluorescent lights in this room were on from 0800 to 1700 hours. Ambient temperature was $20 \pm 3^{\circ} \mathrm{C}$. Infrared heat lamps were provided for basking from 0800 to 1600 hours. The red-eared turtles were kept in tanks with Hlowing water $10 \mathrm{~cm}$ deep at $15 \pm 3^{\circ} \mathrm{C}$ at one end and dry gravel at the other end. They were fed lettuce, bananas, apples, raw pork liver, and a mixture of commercial dog food, cod liver oil, bone ash and vitamin powder (Pervinal). The ornate box turtles were kept in wooden boxes with sand and gravel bottoms. Water was continuously available. They were fed bananas, lettuce and apples, and were occasionally provided with grasshoppers and crickets. Cod liver oil was administered orally twice a week to provide vitamins.

Eight $P$. scripta (mean weight, $305 \mathrm{~g}$; range, 257-353 g) and seventeen $T$. ornata (mean weight, $354 \mathrm{~g}$; range, $180-538 \mathrm{~g}$ ) were used in determining standard and active metabolic and heart rates at body temperatures between 10 and $40^{\circ} \mathrm{C}$. The metabolic rates of these turtles at rest were found to be lowest at night, so measurements of their standard metabolism were carried out between 1900 and 0600 hours. Metabolic rates of active animals were measured between 0900 and 1200 hours since turtles have been found to exhibit their greatest spontaneous activity during the early morning (Brett, 1971). Measurements of $P$. scripta were carried out in March and April of 1972 and of T. ornata in June, July and August of 1972, periods when these species are normally active in nature (Cagle, 1946; Legler, 1960). Since digestion and assimilation of food usually elevate metabolic rate in turtles, all animals were deprived of food for 1 week before use (see Benedict, 1932).

Twenty $P$, scripta (mean weight, $416 \mathrm{~g}$; range, $192-804 \mathrm{~g}$ ) and twenty $T$. ornata (mean weight, $340 \mathrm{~g}$; range, $165-584 \mathrm{~g}$ ) were used in determinations of anaerobic metabolism 
from September to November 1972. Five specimens of each species were used at rest and during activity at 30 and $40^{\circ} \mathrm{C}$. These animals were deprived of food and water for $24 \mathrm{hr}$ preceding use. All measurements were carried out between 0900 and 1700 hours. The extent of any diurnal fluctuations in anaerobic metabolism is not known.

Both male and female turtles of both species were used in this study. No consistent variation in any of the parameters measured can be attributed to differences in sex.

\section{Standard and active metabolic and heart rates}

Metabolic rate and heart rate were determined simultaneously in each test, the former by measurement of oxygen consumption and the latter by electrocardiography. Each turtle was weighed to the nearest $0 \cdot 1 \mathrm{~g}$ and fitted with three silver wire electrodes ( $28 \mathrm{ga}$.) which were inserted $5-10 \mathrm{~mm}$ into the body cavity through $1-\mathrm{mm}$ holes drilled in the carapace (one each in the second right and left lateral scute and one in the fourth left lateral scute). A previously calibrated copper-constantan thermocouple $(30 \mathrm{ga}$.) was inserted $1 \mathrm{~cm}$ into a $1-\mathrm{mm}$ hole drilled in the anterior-medial corner of the right abdominal scute of the plastron. This served to register body temperature in the vicinity of the heart, as confirmed by dissection (see also Spray \& May, 1972; Webb \& Johnson, 1972). The turtle was then placed in a Plexiglass chamber $(22.8 \times 17.8 \times 10.3 \mathrm{~cm})$ which was sealed and the electrodes and thermocouple led out through an airtight port. This chamber was placed in a darkened constant temperature cabinet adjusted to maintain the animals within $0.5^{\circ} \mathrm{C}$ of the desired body temperatures from 10 to $40^{\circ} \mathrm{C}$. The animal chamber contained a small electric fan to provide rapid air circulation during measurement of activity metabolism. The thermocouple was connected to a Honeywell-Brown Type 153 Electronik recording potentiometer to allow monitoring of body temperature.

Because of the highly irregular nature of turtle respiration which is characterized by long periods of apnea (see McCutcheon, 1943; Belkin, 1964; White \& Ross, 1965; Gans \& Hughes, 1967; Gaunt \& Gans, 1969), measurements of turtles in an open-circuit system provided a highly accurate record of minute-to-minute changes in oxygen consumption. These measurements also documented the absence of oxygen consumption during apneic periods and the relatively massive gas exchange occurring during active ventilatory periods. Since integration of oxygen consumption over long periods from such a record is difficult, a closed system, similar to that described by Depocas \& Hart (1957), which sacrifices high minute-to-minute accuracy for a more stable record of oxygen consumption was devised. In measurements of standard metabolic rate, animals were placed in the chamber at 1300 hours and allowed to become accustomed to their environment over the next $4 \mathrm{hr}$. Air was drawn out of the chamber via Tygon tubing by a peristaltic pump and forced at approximately $120 \mathrm{~cm}^{3} / \mathrm{min}$ through a column of drying agent (Drierite), a flowmeter and into a previously calibrated Beckman F3 paramagnetic oxygen analyzer. Air from the outlet port of the analyzer was returned to the animal chamber. The fractional concentration of oxygen in the air passing through the analyzer was recorded continuously from 1700 until 0600 hours the following morning, but only measurements recorded after 1900 hours were used for analysis. In order to keep the percentage of oxygen in the system between 20 and 21 per cent during the period of measurement, the volume of the entire system was adjusted in accordance with the temperature being used by adding chambers of known volume in series with the animal chamber. Since periods of obvious activity were discarded, the measurements approach true standard metabolic rates.

The silver electrodes inserted through the carapace were connected via leads to a Grass P5C preamplifier and a Sanborn 301 recorder. The electrocardiogram was recorded automatically for $1 \mathrm{~min}$ of each hour from 2200 until 0600 hours. The standard heart rate was calculated from the interval between $R$ waves of the electrocardiogram. Periods of activity, as indicated by large muscle potentials, were omitted.

Metabolic and heart rates of active animals were deternined for the same individuals and in the same chamber as in the standard measurements. Two or three measurements 
of each animal at the various temperatures were made 1-1.5 hr apart between 0900 and 1200 hours in the morning following recording of standard metabolic and heart rates. Air in the chamber was circulated continuously by the small electric fan during these determinations. At the beginning of each measurement the chamber was flushed with dry air for 5 min. A balloon was placed over the outlet port of the chamber and air rapidly pumped into the chamber by the peristaltic pump, thus causing the balloon to be inflated with a well-mixed sample of approximately $300 \mathrm{~cm}^{3}$ of chamber air. The balloon was removed and the air it contained allowed to pass at approximately $80 \mathrm{~cm}^{3} / \mathrm{min}$ through a tube of Drierite and then into the oxygen analyzer. The turtle was then stimulated to maximal activity for $2 \mathrm{~min}$ by electric shocks of $0 \cdot 1-15 \cdot 0 \mathrm{~V}, 50$ pulses/sec, $10 \mathrm{msec}$ duration from a Grass S4C stimulator delivered via the electrodes normally used for heart rate recording. Both species responded to shocks by rapid swimming or running movements of the limbs. Their response was violent and therefore appeared to be the maximal activity level possible at each tcmpcrature. No significant rise in body temperature occurred during activity, as in turtles induced to activity by Boyer $(1965, \mathrm{p} .101)$. At the end of the stimulation period, the electrodes were again attached to the preamplifier and heart rate was recorded for $1 \mathrm{~min}$. It was assumed that immediate post-activity heart rate closely approximates heart rate during activity. At the same time that heart rate was being recorded, a second balloon was placed over the exit air port and inflated by rapidly reducing the volume of the animal chamber. This was achieved by inflating a third balloon located inside the chamber and connected to the outside via a tube. The contents of the second balloon therefore represented a well-mixed sample of approximately $200 \mathrm{~cm}^{3}$ of the air in the chamber at the end of the activity period. This air was allowed to flow through the Drierite tube and into the oxygen analyzer at approximately $40 \mathrm{~cm}^{3} / \mathrm{min}$. The active metabolic rate was calculated from the decrement in fractional concentration of oxygen in the system over the 2-min period.

\section{Anaerobic metabolism}

The extent of anaerobiosis during activity was determined by measuring total body lactic acid concentration in ten turtles of each species at rest and in ten induced to vigorous exercise, half at body temperatures of $30^{\circ} \mathrm{C}$ and half at $40^{\circ} \mathrm{C}$. The former is near the thermal preferendum of both species (see Gatten, 1974) and the latter is the temperature at which their aerobic capacities are greatest (see below).

Between 18 and $24 \mathrm{hr}$ preceding a measurement, a turtle was weighed to the nearest $0.1 \mathrm{~g}$, and a $13 \mathrm{~mm}$ dia hole was drilled through the plastron over the heart and then closed with a snug-fitting cork. This procedure allowed rapid access to the arterial blood supply. Data from blood measurements will be reported elsewhere. If an animal was to be measured during activity, it was equipped with two silver wire electrodes (28 ga.) inserted $5-10 \mathrm{~mm}$ into the body cavity through $1 \mathrm{-mm}$ holes drilled in the carapace, one anteriorly and one posteriorly. Animals to be measured in a resting state were not so equipped. All animals were then allowed to rest undisturbed overnight in a darkened temperature cabinet adjusted to maintain body temperature at $30 \pm 1^{\circ} \mathrm{C}$ or $40 \pm 1^{\circ} \mathrm{C}$. On the following morning, animals to be induced to activity were stimulated as in the determinations of aerobic activity metabolism. At the end of the activity period the turtle was removed from the temperature cabinet and the elcctrodes were rapidly pulled out. Resting animals were not disturbed prior to their removal from the cabinet. Each turtle was then placed immediately in liquid nitrogen at $-196^{\circ} \mathrm{C}$, where freezing was rapid. The maximum interval between removing a turtle from the cabinet and immersing it in the liquid nitrogen was 30 sec.

Total body lactate was determined from a homogenate of the whole body. The intact turtle was removed from the liquid nitrogen, broken into pieces $0.1-2.0 \mathrm{~cm}$ in diameter with a hammer and chisel, placed in an amount of $0.6 \mathrm{~N}$ perchloric acid four times its volume and ground in a commercial blender at maximum speed for 5 min. A portion of the resultant suspension (residual pieces of shell and bone 1-2 mm) was centrifuged for $10 \mathrm{~min}$ in a 
bench centrifuge. The supernatant was frozen for later analysis of total body lactate by an enzymatic method (Boehringer Mannheim test kit, Cat. No. 15972). The precipitate which formed when the buffer was added to the supernatant was removed by centrifugation immediately prior to spectrophotometric measurement with a Carey 17 Spectrophotometer set at $366 \mathrm{~nm}$. Total body lactate was computed as $\mathrm{mg}$ lactate $/ 100 \mathrm{ml}$ of body fluid and then converted to $\mathrm{mg}$ lactate/g of body weight.

\section{Statistical analysis}

Equations describing the relationship of metabolic and heart rates to temperature were computed by the method of least squares. In cases where a function was clearly non-linear, polynomial regressions of increasing order were computed until no significant improvement in fit was obtained. Confidence limits around the slope $(b)$ of linear regressions were based on twice the standard error of the slope. Analysis of variance for total body lactate was carried out to determine the contribution of species, temperature level and activity level to the observed variation. Also, $t$-tests between means were carried out for total body lactate for species, temperature and activity levels. Statistical significance was assumed when $P<0 \cdot 05$.

\section{RESULTS}

\section{Standard and active metabolic rate}

Values for metabolic rate are expressed as oxygen consumption $\left(\dot{V}_{\mathrm{O}_{2}}\right)$ in $\mathrm{cm}^{3}$ $\mathrm{O}_{2} /(\mathrm{g} \times \mathrm{hr})$ at STPD. Body temperatures $\left(T_{\mathrm{b}}\right)$ are expressed in degrees Celsius $\left({ }^{\circ} \mathrm{C}\right)$. The linear equation relating standard metabolic rate to body temperature in P. scripta (Fig. 1) is

$$
\left.\begin{array}{l}
\log \mathrm{SMR}=-2 \cdot 8780+0.0458\left(T_{\mathrm{b}}\right) \\
N=25, \quad r=0.98, \quad b=0.0458 \pm 0.0043 .
\end{array}\right\}
$$

The $Q_{10}$ for this relationship is $2 \cdot 87$.

The metabolic rate of red-eared turtles stimulated to activity increases with increasing body temperature from 10 to $32^{\circ} \mathrm{C}$ but tends to remain constant from 32 to $38^{\circ} \mathrm{C}$ (Fig. 1). A slight decrease is apparent at $40^{\circ} \mathrm{C}$. The equation best describing this relationship is

$$
\left.\begin{array}{l}
\log \mathrm{AMR}=-1 \cdot 7541+0.0754\left(T_{\mathrm{b}}\right)-0.00078\left(T_{\mathrm{b}}\right)^{2} \\
N=57, \quad r=0.89
\end{array}\right\}
$$

Since this equation predicts that active metabolic rate will increase continuously between 10 and $40^{\circ} \mathrm{C}$, it slightly overestimates the actual value of active metabolism at $38-40^{\circ} \mathrm{C}$. The $Q_{10}$ values calculated from this polynomial are given in Table 1. The ratio of active to standard metabolic rate in $P$. scripta reaches a maximum of 25.4 at $19^{\circ} \mathrm{C}$ and a minimum of 11.4 at $40^{\circ} \mathrm{C}$.

The polynomial equation describing the relationship between standard metabolic rate and body temperature in T. ornata (Fig. 2) is

$$
\begin{aligned}
& \log \mathrm{SMR}=-9 \cdot 7024+1 \cdot 1661\left(T_{\mathrm{b}}\right)-0.0650\left(T_{\mathrm{b}}\right)^{2} \\
& \quad+0.0016\left(T_{\mathrm{b}}\right)^{3}-0.000013\left(T_{\mathrm{b}}\right)^{4} \\
& N=31, \quad r=0.97 .
\end{aligned}
$$

The $Q_{10}$ values based on equation (3) are given in Table 1 . 
Table $1-Q_{10}$ values for some metabolic and heart Rates IN $P$. scripta and $T$. ornata

\begin{tabular}{ccccc}
\hline $\begin{array}{c}T_{\mathrm{b}} \text { range } \\
\left({ }^{\circ} \mathrm{C}\right)\end{array}$ & $\begin{array}{c}Q_{10} \text { for active } \\
\text { metabolic rate } \\
\text { in } P . \text { scripta }\end{array}$ & $\begin{array}{c}Q_{10} \text { for standard } \\
\text { metabolic rate } \\
\text { in } T \text {. ornata }\end{array}$ & $\begin{array}{c}Q_{10} \text { for active } \\
\text { metabolic rate } \\
\text { in } T \text {. ornata }\end{array}$ & $\begin{array}{c}Q_{10} \text { for active } \\
\text { heart rate } \\
\text { in } P . \text { scripta }\end{array}$ \\
\hline $10-15$ & 3.63 & 54.38 & 25.97 & $2 \cdot 86$ \\
$15-20$ & 3.02 & 2.74 & 5.83 & $2 \cdot 45$ \\
$20-25$ & 2.53 & 1.25 & 2.21 & $2 \cdot 10$ \\
$25-30$ & 2.11 & 2.08 & 1.41 & 1.80 \\
$30-35$ & 1.76 & 5.07 & 1.51 & 1.54 \\
$35-40$ & 1.47 & 7.34 & 2.70 & 1.32 \\
\hline
\end{tabular}

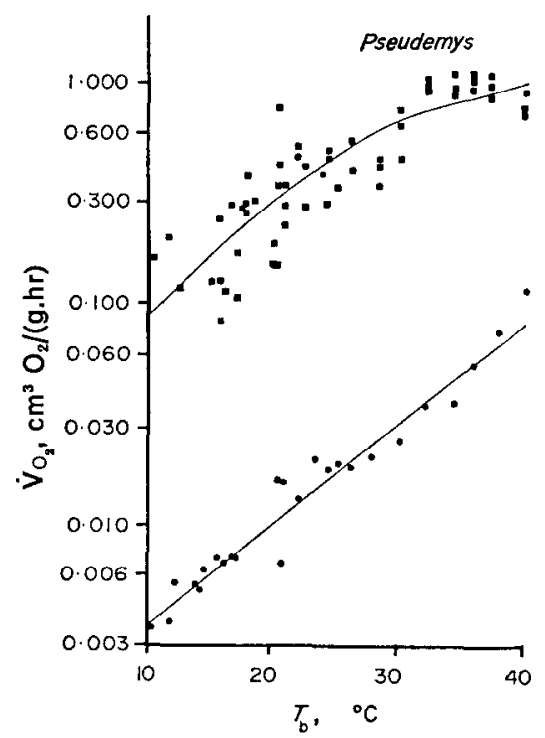

FIG. 1. Standard and active metabolic rates $\left(V_{\mathrm{O}_{2}}\right)$ in P. scripta. Each circle is the mean of approximately $10 \mathrm{hr}$ of measurement of standard metabolic rate of an individual at a given temperature; squares represent individual determinations of active metabolic rate. Regression lines were constructed on the basis of equations

(1) and (2).

Metabolic rate in active ornate box turtles rises with increasing body temperature from 10 to $34^{\circ} \mathrm{C}$, but tends to remain constant from 34 to $40^{\circ} \mathrm{C}$ (Fig. 2). The polynomial best describing the data is

$$
\begin{gathered}
\log \text { AMR }=-4.6077+0.4003\left(T_{\mathrm{b}}\right)-0.0132\left(T_{\mathrm{b}}\right)^{2} \\
\quad+0.00015\left(T_{\mathrm{b}}\right)^{3} \\
N=61, \quad r=0.95 .
\end{gathered}
$$

Since this equation predicts that active metabolic rate increases continuously with increasing temperature, it tends to overestimate slightly the actual oxygen 


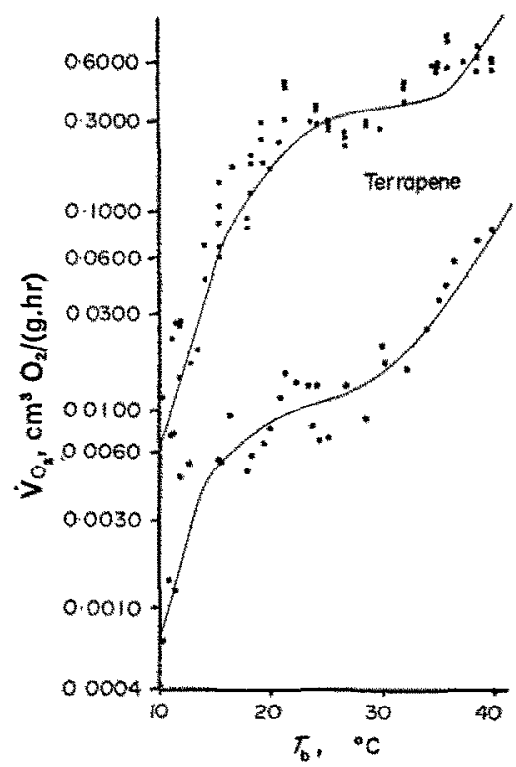

Frg. 2. Standard and active metabolic rates $\left(V_{O_{2}}\right)$ in $T$. ornata. Each circle is the mean of approximately $10 \mathrm{hr}$ of measurement of standard metabolic rate of an individual at a given temperature; squares represent individual determinations of active metabolic rate. Regression lines were constructed on the basis of equations

(3) and (4).

consumption of active turtles between 38 and $40^{\circ} \mathrm{C}$. The $Q_{10}$ values for active metabolic rate based on Equation 4 are given in Table 1. In T. ornata metabolism shows a maximum $29 \cdot 6$-fold increase during activity at $26^{\circ} \mathrm{C}$ and a minimum eight-fold increase at $40^{\circ} \mathrm{C}$.

Aerobic metabolic scope (Fig. 3), the difference between active and standard rates of oxygen consumption, indicates the amount of energy available for activity beyond that required for maintenance of other body functions (Fry, 1947). In both species, scope increases continuously with increasing temperature, reaching maximum values at $40^{\circ} \mathrm{C}$ of 0.94 and $0.64 \mathrm{~cm}^{3} \mathrm{O}_{2} /(\mathrm{g} \times \mathrm{hr})$ for $P$. scripta and $T$. ornata, respectively. Since equations (2) and (4) slightly overestimate active metabolic rate for both species at body temperatures approaching $40^{\circ} \mathrm{C}$, these predictions of metabolic scope are also slight overestimates. Table 2 summarizes values for standard and active metabolic rate and metabolic scope at $10,20,30$ and $40^{\circ} \mathrm{C}$.

\section{Standard and active heart rate}

In the following equations heart rates (HR) are expressed in beats/min and body temperature $\left(T_{\mathrm{b}}\right)$ in degrees Celsius $\left({ }^{\circ} \mathrm{C}\right)$. The regression line relating 


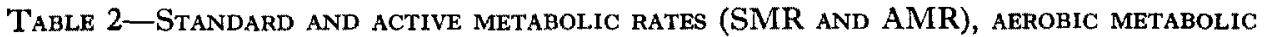
SCOPE, STANDARD AND ACTIVE HEART RATES (SHR AND AHR), HEART RATE INCREMENT (HR inc.), STANDARD AND ACTIVE OXYGEN PULSE (SOP AND AOP) AND OXYGEN PULSE INCREMENT (OP inc.) IN $P$. scripta AND $T$. ornata AT $10,20,30$ AND $40^{\circ} \mathrm{C}$

\begin{tabular}{|c|c|c|c|c|c|}
\hline & & $10^{\circ} \mathrm{C}$ & $20^{\circ} \mathrm{C}$ & $30^{\circ} \mathrm{C}$ & $40^{\circ} \mathrm{C}$ \\
\hline P. scripta & SMR & $0 \cdot 0038$ & $0 \cdot 0109$ & 0.0313 & 0.0899 \\
\hline$T$. ornata & SMR & 0.0008 & 0.0093 & 0.0149 & 0.0912 \\
\hline P. scripta & AMR & 0.0835 & 0.2764 & 0.6383 & 1.0283 \\
\hline$T$. ornata & AMR & 0.0167 & 0.2055 & $0 \cdot 3625$ & $0 \cdot 7316$ \\
\hline P. scripta & Scope & 0.0797 & 0.2655 & 0.6070 & 0.9384 \\
\hline T. ornata & Scope & 0.0159 & 0.1962 & 0.3476 & 0.6404 \\
\hline P. scripta & SHR & $5 \cdot 5$ & $10 \cdot 6$ & $20 \cdot 6$ & $39 \cdot 7$ \\
\hline T. ornata & SHR & $3 \cdot 3$ & 6.7 & $13 \cdot 5$ & $27 \cdot 2$ \\
\hline P. scripta & AHR & 12.7 & $33 \cdot 6$ & $65 \cdot 2$ & $93 \cdot 1$ \\
\hline T. ornata & AHR & $22 \cdot 4$ & $36 \cdot 0$ & 57.9 & $93 \cdot 0$ \\
\hline P. scripta & HR inc. & $7 \cdot 2$ & $23 \cdot 0$ & $44 \cdot 6$ & $53 \cdot 4$ \\
\hline$T$. ornata & HR inc. & $19 \cdot 1$ & $29 \cdot 3$ & $44 \cdot 4$ & 65.8 \\
\hline P. scripta & SOP & $1 \cdot 15$ & 1.71 & 2.54 & 3.77 \\
\hline T. ornata & SOP & 0.38 & $2 \cdot 31$ & 1.85 & $5 \cdot 59$ \\
\hline$P$. scripta & $\mathrm{AOP}$ & 10.98 & 13.73 & $16 \cdot 31$ & $18 \cdot 42$ \\
\hline T. ornata & AOP & 1.25 & $9 \cdot 52$ & $10 \cdot 44$ & $13 \cdot 11$ \\
\hline P. scripta & $\mathrm{OP}$ inc. & 9.83 & 12.02 & 13.77 & 14.65 \\
\hline T. ornata & OP inc. & $0 \cdot 87$ & $7 \cdot 21$ & 8.59 & $7 \cdot 52$ \\
\hline
\end{tabular}

Metabolic values were calculated from equations (1) to (4) and are given in $\mathrm{cm}^{3} \mathrm{O}_{2} /(\mathrm{g} \times \mathrm{hr})$ at STPD. Heart rate values were calculated from equations (5) to (8) and are given in beats/min. Oxygen pulse values were calculated from equation (1) to (8) and are given in $\mathrm{cm}^{3} \mathrm{O}_{2} \times 10^{5} /(\mathrm{g} \times$ beat $)$.

standard heart rate and body temperature in P. scripta (Fig. 4) is

$$
\left.\begin{array}{l}
\log \operatorname{SHR}=0.4557+0.0286\left(T_{\mathrm{b}}\right) \\
N=27, \quad r=0.94, \quad b=0.0286 \pm 0.0042 .
\end{array}\right\}
$$

The $Q_{10}$ for standard heart rate is 1.93 .

The effect of body temperature on heart rate in active red-eared turtles (Fig. 4) is best described by the polynomial

$$
\left.\begin{array}{l}
\log \mathrm{AHR}=0.5461+0.0624\left(T_{\mathrm{b}}\right)-0.00067\left(T_{\mathrm{b}}\right)^{2} \\
N=56, \quad r=0.95
\end{array}\right\}
$$

The $Q_{10}$ values based on equation (6) are given in Table 1 . In $P$. scripta, heart rate increases maximally during activity by a factor of 3.3 at $25^{\circ} \mathrm{C}$ and minimally by a factor of $2 \cdot 3$ at both 10 and $40^{\circ} \mathrm{C}$.

The linear relationship between standard heart rate and body temperature in $T$, ornata (Fig. 5) is

$$
\left.\begin{array}{l}
\log \operatorname{SHR}=0.2192+0.0304\left(T_{\mathrm{b}}\right) \\
N=32, \quad r=0.91, \quad b=0.0304 \pm 0.0051 .
\end{array}\right\}
$$

The $Q_{10}$ for standard heart rate is $2 \cdot 01$. 


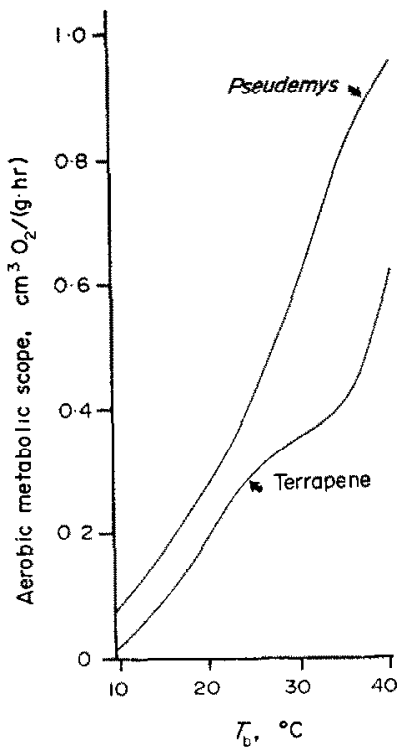

Fic. 3. Aerobic metabolic scope in $P$. scripta and T. ornata. Regression lines were constructed on the basis of equations (1)-(4).

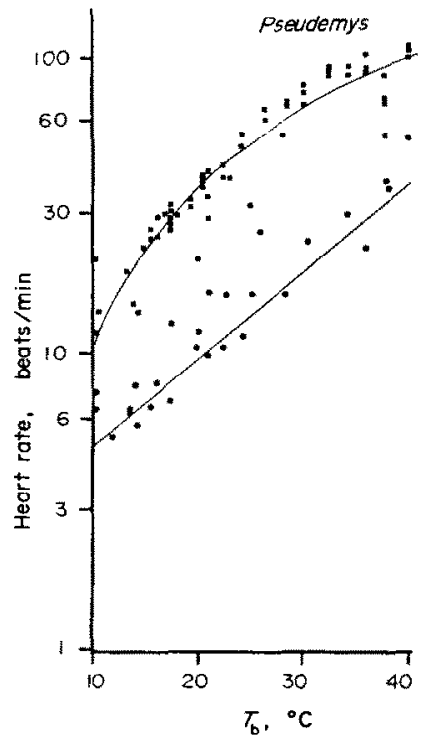

Fig. 4. Standard and active heart rates in P. scripta. Each circle is the mean of approximately $9 \mathrm{~min}$ of measurement of standard heart rate of an individual at a given temperature; squares represent individual determinations of active heart rate. Regression lines were constructed on the basis of equations (5) and (6). 
In ornate box turtles stimulated to activity, heart rate increases linearly with temperature (Fig. 5) according to the equation

$$
\left.\begin{array}{l}
\log \text { AHR }=1 \cdot 1437+0.0206\left(T_{\mathrm{b}}\right) \\
N=60, \quad r=0.93, \quad b=0.0206 \pm 0.0021 .
\end{array}\right\}
$$

The $Q_{10}$ for active heart rate is 1.61. A $t$-test indicates that the slopes of equations $(7)$ and $(8)$ do not differ significantly $(P>0.05)$. In $T$. ornata the ratio of active to standard heart rate declines from a maximum of 6.8 at $10^{\circ} \mathrm{C}$ to a minimum of 3.4 at $40^{\circ} \mathrm{C}$.

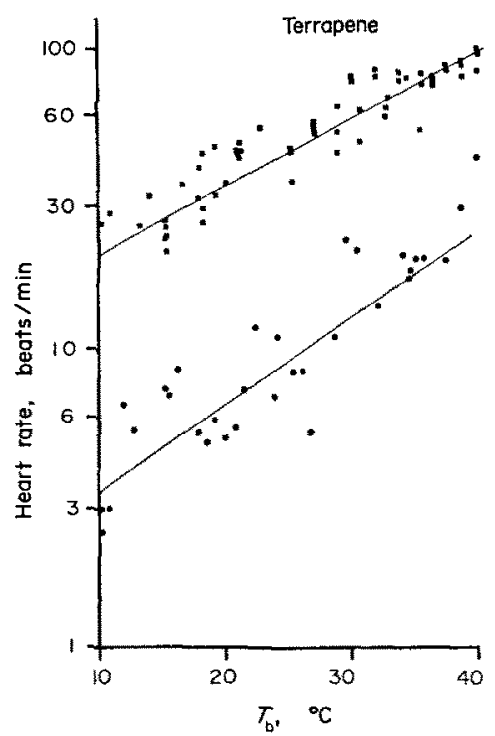

Fig. 5. Standard and active heart rates in T. ornata. Each circle is the mean of approximately $9 \mathrm{~min}$ of measurement of standard heart rate of an individual at a given temperature; squares represent individual determinations of active heart rate.

Regression lines were constructed on the basis of equations (7) and (8).

Heart rate increment (Fig. 6) is the difference between active heart rate and standard heart rate and is analogous to metabolic scope. Heart rate increment is maximum in both species at $40^{\circ} \mathrm{C}$, with values of 53.4 beats/min for $P$. scripta and 65.8 beats/min in $T$. ornata. Values for the two species are within a range of $1 \mathrm{beat} / \mathrm{min}$ from 27 to $34^{\circ} \mathrm{C}$. Table 2 summarizes values for standard and active heart rate and heart rate increment at $10,20,30$ and $40^{\circ} \mathrm{C}$.

Standard and active oxygen pulse

Under steady-state conditions the Fick equation

$$
V_{O_{1}}=\text { Heart rate } \times \text { Stroke volume } \times A-V \text { difference, }
$$

states that oxygen consumption $\left(V_{O_{\mathrm{o}}}\right)$ will equal the product of cardiac output 


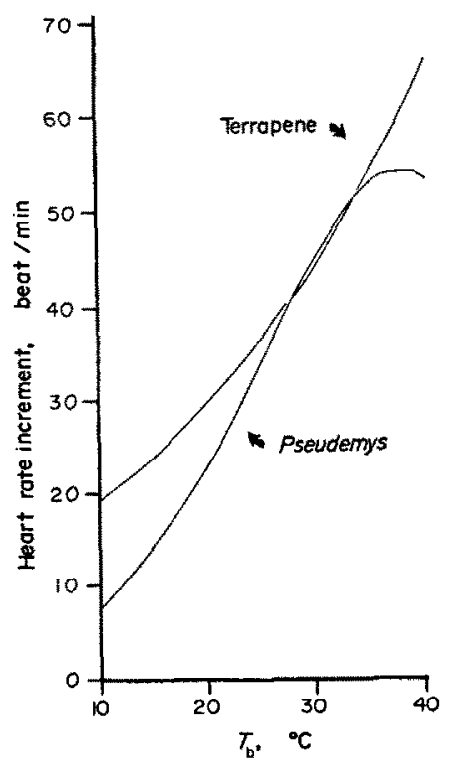

Fic. 6. Heart rate increment in $P$. scripta and $T$. ornata. Regression lines were constructed on the basis of equations (5) $-(8)$.

(heart rate $\times$ stroke volume) and the amount of oxygen extracted from the blood in its passage from arterial to venous portions of the heart ( $A-V$ difference). Rearranged, equation (9) becomes

$$
\frac{V_{O_{1}}}{\text { Heart rate }}=\text { Oxygen pulse }=\text { Stroke volume } \times A-V \text { difference } .
$$

Thus, oxygen pulse indicates the amount of oxygen consumed per heart beat and is usually expressed as $\mathrm{cm}^{3} \mathrm{O}_{2} /(\mathrm{g} \times$ beat $)$. A change in oxygen pulse indicates a change in stroke volume and/or a change in the amount of oxygen extracted from the blood by the tissues. Since both metabolic and heart rates were measured here, the alteration in oxygen pulse with change in temperature and activity in P. scripta (Fig. 7) and T. ornata (Fig. 8) can be quantified.

The difference between the active oxygen pulse and the standard oxygen pulse of reptiles is a parameter that has not been analyzed previously. This parameter has been termed oxygen pulse increment (Fig. 9) and indicates the amount by which the product of stroke volume and arterial-venous oxygen difference changes with activity. Thus, it is analogous to metabolic scope and heart rate increment. Table 2 summarizes values for standard and active oxygen pulse and oxygen pulse increment at $10,20,30$ and $40^{\circ} \mathrm{C}$. The percentage contribution of the increase in heart rate to the increase in oxygen transport during activity in these turtles will be discussed in a subsequent paper (Gatten, 1974b). 


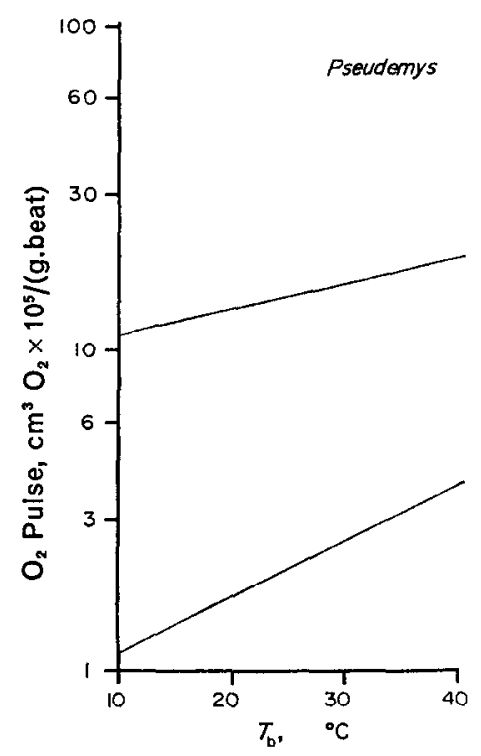

FIG. 7. Standard and active oxygen pulse in P. scripta. Regression lines were constructed on the basis of equations (1), (2), (5) and (6).

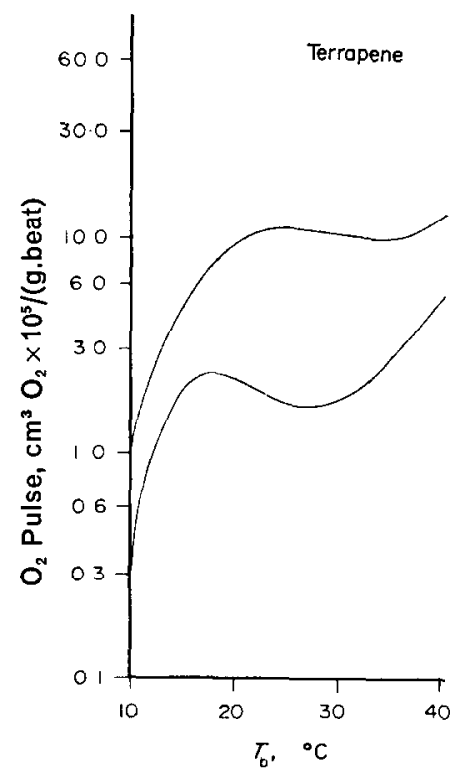

FIG. 8. Standard and active oxygen pulse in $T$. ornata. Regression lines were constructed on the basis of equations (3), (4), (7) and (8). 


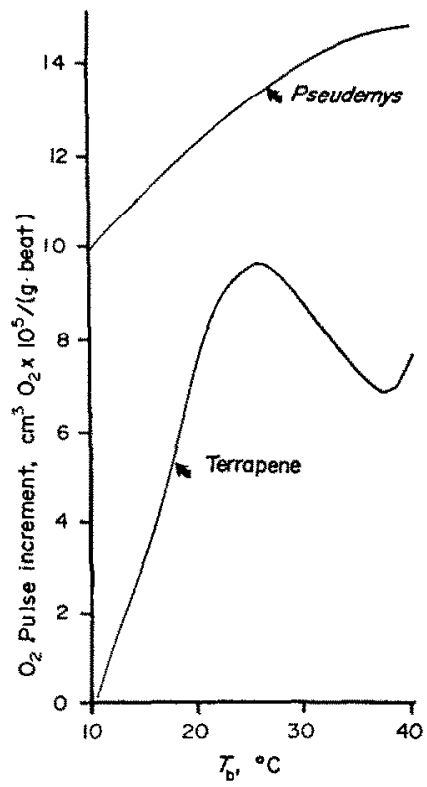

FIG. 9. Oxygen pulse increment in $P$. scripta and $T$. ornata. Regression lines were constructed on the basis of equations (1)-(8).

\section{Total body lactate concentration}

The effect of difference in species, temperature and activity level on total body lactate is indicated in Fig. 10 and Table 3. Variation in this parameter is due mainly to species differences $(P=0.0039)$ and activity of the animals $(P=0.0002)$. Body temperature is an insignificant factor in the variation of total body lactate $(P=$ 0.9793 ). The total amount of lactate in the body increases in $P$. scripta from rest to activity only at $30^{\circ} \mathrm{C}$ and in $T$. ornata from rest to activity at both temperature levels. Red-eared turtles have higher total body lactate levels than ornate box turtles at $30^{\circ} \mathrm{C}$ at rest and at $40^{\circ} \mathrm{C}$ during activity.

\section{DISCUSSION}

\section{Standard metabolic rate}

Both $P$. scripta and $T$. ornata have preferred body temperatures in a thermal gradient and mean body temperatures during activity in nature of near $30^{\circ} \mathrm{C}$ (see Gatten, 1974). Consequently, comparisons of their metabolic capabilities at this body temperature are particularly meaningful. Results of this study indicate that standard metabolic rate is generally higher in red-eared turtles than in ornate box turtles, especially at lower body temperatures. The values for standard metabolic rate reported in this study are substantially lower than those reported by others for turtles of the same weight at similar body temperatures (see Bennett 


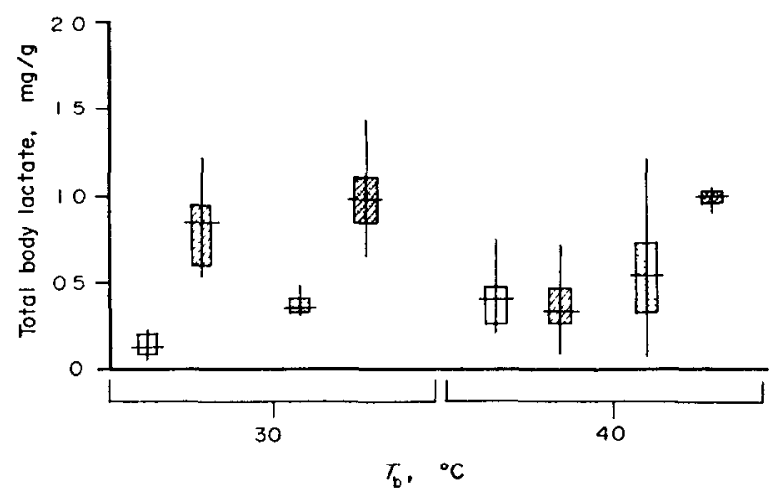

Fig. 10. Concentration of total body lactate in P. scripta and T. ornata at 30 and $40^{\circ} \mathrm{C}$ during rest and activity. Horizontal bar $=$ mean, vertical bar $=$ range, rectangle $=2$ standard errors of the mean; unshaded rectangle $=P$. scripta at rest, rectangle with lines $=P$. scripta during activity, rectangle with dots $=T$. ornata at rest, rectangle with dots and lines $=T$. ornata during activity.

Table 3-Concentration of total body Lactate in $P$. scripta and $T$. ornata at Rest AND DURING 2 min OF MAXIMAL ACTIVITY AT 30 AND $40^{\circ} \mathrm{C}$

\begin{tabular}{lc}
\hline $\begin{array}{c}\text { Species, temperature }\left({ }^{\circ} \mathrm{C}\right), \\
\text { condition }\end{array}$ & $\begin{array}{c}\text { Total body lactate } \\
(\mathrm{mg} / \mathrm{g})\end{array}$ \\
\hline$P$. scripta, 30, resting & $0 \cdot 18 \pm 0.02$ \\
$P$. scripta, 30, active & $0.73 \pm 0.13$ \\
$T$. ornata, 30, resting & $0.39 \pm 0.04$ \\
$T$. ornata, 30, active & $0.98 \pm 0.14$ \\
$P$. scripta, 40, resting & $0 \cdot 38 \pm 0.10$ \\
$P$. scripta, 40, active & $0 \cdot 37 \pm 0.10$ \\
$T$. ornata, 40, resting & $0.55 \pm 0.18$ \\
$T$. ornata, 40, active & $1.00 \pm 0.04$ \\
\hline
\end{tabular}

Values are means \pm 1 S.E. Sample size in each case is five.

\& Dawson, 1971). Bennett \& Dawson's (1974) equation (20) predicts standard metabolic rates at $20^{\circ} \mathrm{C}$ of 0.0296 and $0.290 \mathrm{~cm}^{3} \mathrm{O}_{2} /(\mathrm{g} \times \mathrm{hr})$ for turtles the size of $P$. scripta and $T$. ornata, respectively. These values are appreciably higher than 0.0109 and $0.0093 \mathrm{~cm}^{3} \mathrm{O}_{2} /(\mathrm{g} \times \mathrm{hr})$, the standard metabolic rates measured in these species in the present study. The high rates of oxygen consumption reported by other authors can be attributed, at least in part, to the fact that many of their studies did not involve truly minimal, standard conditions. Resting metabolic rates of reptiles determined during diurnal periods may be twice as great as those measured at night (Roberts, 1968). Also, activity profoundly affects metabolism, as will be discussed below. 
The $Q_{10}$ for standard metabolic rate in $P$. scripta remains constant at 2.87 from 10 to $40^{\circ} \mathrm{C}$ whereas that of $T$. ornata reaches the amazingly high value of 54.38 between 10 and $15^{\circ} \mathrm{C}$, tapers off to more conventional values of $1-3$ between 15 and $30^{\circ} \mathrm{C}$ and then rises to 7.34 between 35 and $40^{\circ} \mathrm{C}$. Red-eared turtles are normally active in nature at body temperatures of $10-37^{\circ} \mathrm{C}(\mathrm{Cagle}, 1946)$ and thus a constant $Q_{10}$ over that range is not uncxpected. Ornate box turtles are normally active at body temperatures of $15-35^{\circ} \mathrm{C}$ (Legler, 1960); therefore, a greater thermal dependence of metabolism between 10 and $15^{\circ} \mathrm{C}$ and between 35 and $40^{\circ} \mathrm{C}$ is not surprising. The presence of a relatively flat region in the curve shown in Fig. 2 for standard metabolism in ornate box turtles, with $Q_{10}$ values of $1.25-2.09$ between 20 and $30^{\circ} \mathrm{C}$, indicates relatively low thermal dependence of metabolic rate in this range. Even more pronounced plateaus in metabolic rate in temperature spans over which animals are normally active in nature have been found in other reptiles (Buikema \& Armitage, 1969; Aleksiuk, 1971; Jacobson \& Whitford, 1970, 1971; Bennett, 1972; Bennett \& Dawson, 1972) and may be an indication of partial homeostasis in the response of metabolism to temperature (Dawson \& Bartholomew, 1956).

These turtles at $30^{\circ} \mathrm{C}$ appear to have standard metabolic rates $17-35$ per cent of those predicted for lizards of the same size and $21-42$ per cent of those predicted for similar-sized reptiles (Table 4). Similarly, some snakes appear to have standard

Table 4 -Standard metabolic rates of P. scripta (305 g) and $T$. ornata (354 g) AS A PERCFNTAGE OF THOSE OF OTHER VERTEBRATES

\begin{tabular}{lccl}
\hline & P. scripta & T. ornata & Reference \\
\hline Lizards & 34.5 & 16.9 & $\begin{array}{c}\text { Bennett \& Dawson (1974, } \\
\text { equation 11) }\end{array}$ \\
Reptiles & 42.0 & 20.7 & $\begin{array}{c}\text { Bennett \& Dawson (1974, } \\
\text { equation 23) }\end{array}$ \\
Mammals & 7.9 & 6.3 & Kleiber (1961) \\
Non-passerine birds & 6.8 & 5.5 & Lasiewski \& Dawson (1967) \\
\hline
\end{tabular}

The standard metabolic rates are expressed as a percentage of the predicted values of standard metabolic rate for lizards and reptiles of the same body weight at $30^{\circ} \mathrm{C}$, and of the predicted levels of basal metabolic rate of mammals and non-passerine birds of the same body weight at $37^{\circ} \mathrm{C}$.

metabolic rates approximately half those of lizards of the same size at $30^{\circ} \mathrm{C}$ (Greenwald, 1971; Jacobson \& Whitford, 1971). Whether these differences are due to real variation in metabolism among the orders and suborders of reptiles or simply reflect non-uniformity of experimental conditions must await further study. The latter is the more likely explanation (see Bennett \& Dawson, 1974, for a more complete discussion of variation of metabolism among reptiles). These turtles at $37^{\circ} \mathrm{C}$ have 6-8 per cent of the resting metabolic rates of birds and mammals of the same weight, whereas lizards at $37^{\circ} \mathrm{C}$ consume 9-20 per cent as much oxygen as do these homeotherms (Bennett \& Dawson, 1974). 


\section{Active metabolic rate}

$P$. scripta have a higher active metabolic rate than $T$. ornata at all body temperatures. The majority of this difference is probably correlated with the fact that red-eared turtles are considered to be active, quick and alert animals whereas ornate box turtles are more lethargic (Cahn, 1937). Scattered reports of nonmaximal active metabolic rates of chelonians exist in the literature (Table 5), all

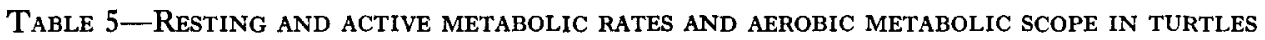

\begin{tabular}{|c|c|c|c|c|c|c|}
\hline Species & $\begin{array}{c}T_{\mathrm{b}} \\
\left({ }^{\circ} \mathrm{C}\right)\end{array}$ & $\begin{array}{l}\text { Body wt. } \\
\text { (g) }\end{array}$ & $\begin{array}{c}\text { Resting } \\
\text { MR }\end{array}$ & $\begin{array}{l}\text { Active } \\
\text { MR }\end{array}$ & Scope & Reference \\
\hline Chelydra serpentina* & $20 \cdot 0$ & $1345-1930$ & $0 \cdot 0195$ & 0.0582 & $0 \cdot 0387$ & $\begin{array}{l}\text { Baldwin } \\
\quad(1926 a, b)\end{array}$ \\
\hline $\begin{array}{r}\text { Chrysemys picta* } \\
(\text { C. marginata })\end{array}$ & $20 \cdot 0$ & $1088-1447$ & 0.0261 & 0.0491 & 0.0230 & $\begin{array}{l}\text { Baldwin } \\
\quad(1926 \mathrm{a}, \mathrm{b})\end{array}$ \\
\hline Sternothaerus minor $\dagger$ & $22.0 \ddagger$ & $150-200$ & $0 \cdot 0179$ & 0.0784 & 0.0605 & Belkin (1965) \\
\hline Sternothaerus minor $\S$ & $22 \cdot 0 \ddagger$ & 121 & $0 \cdot 0202$ & 0.0403 & 0.0201 & $\begin{array}{l}\text { Belkin } \\
\quad(1968 \mathrm{a})\end{array}$ \\
\hline Sternothaerus odoratus & $25.0 \ddagger$ & Not given & $0 \cdot 0209$ & $0 \cdot 1410$ & $0 \cdot 1201$ & Root (1949) \\
\hline Testudo gigantea & $25.5 \ddagger$ & $\begin{array}{r}100 \\
1000 \\
10,000 \\
100,000\end{array}$ & $\begin{array}{l}0 \cdot 0686 \\
0 \cdot 0454 \\
0 \cdot 0301 \\
0 \cdot 0199\end{array}$ & $\begin{array}{l}0 \cdot 1514 \\
0 \cdot 1408 \\
0 \cdot 1310 \\
0 \cdot 1219\end{array}$ & $\begin{array}{l}0.0828 \\
0.0954 \\
0.1009 \\
0.1020\end{array}$ & $\begin{array}{l}\text { Hughes et al } \\
\text { (1971) }\end{array}$ \\
\hline
\end{tabular}

Resting values are not necessarily standard (minimum) and active values are not necessarily maximal. Therefore, metabolic scope values may not be maximal. Values are given in $\mathrm{cm}^{3} \mathrm{O}_{2} /(\mathrm{g} \times \mathrm{hr})$.

* Resting animals were fasted for 4 weeks; active animals were recently captured.

+ Both resting and active turtles were recently fed.

$\ddagger$ Ambient temperature.

\$ Aquatic oxygen uptake by submerged turtles in oxygen-equilibrated water.

|l Based on one very active and one very quiet turtle.

of which are lower than the active metabolic rates determined here. Bennett \& Dawson (1974) present an equation [equation (27)] relating weight-specific active metabolic rate to body size in fourteen species of reptiles at $30^{\circ} \mathrm{C}$. This equation predicts active metabolic rates of 0.500 and $0.487 \mathrm{~cm}^{3} \mathrm{O}_{2} /(\mathrm{g} \times \mathrm{hr})$ for 305 - and $354-g$ reptiles, respectively, while values found in the present study are 0.6383 and $0.3625 \mathrm{~cm}^{3} \mathrm{O}_{2} /(\mathrm{g} \times \mathrm{hr})$ for $P$. scripta and $T$. ornata, respectively. Thus, it appears that red-eared turtles have higher than anticipated rates of oxygen consumption during activity and ornate box turtles have lower ones.

The $Q_{10}$ for active metabolic rate in $P$. scripta decreases continuously from 3.63 at $10-15^{\circ} \mathrm{C}$ to 1.47 at $35-40^{\circ} \mathrm{C}$. In T. ornata, on the other hand, it decreases from the unusually high value of 25.97 at $10-15^{\circ} \mathrm{C}$ to 1.41 at $25-30^{\circ} \mathrm{C}$, but rises again from 30 to $40^{\circ} \mathrm{C}$. The shape of the metabolism curve as well as the pattern 
of change in $Q_{10}$ are similar in resting and active ornate box turtles. The relationship of activity metabolism to body temperature in red-eared turtles is more like that in other reptiles where $Q_{10}$ is commonly $2-4$ below the thermal preferendum and tends to decline to near unity above the preferred body temperature (Bennett $\&$ Dawson, 1974). The $Q_{10}$ for active metabolism is generally lower than that for standard metabolism in both species of turtles studied herc, as is the casc in several lizards (Dawson, 1967).

Active oxygen consumption is always at least eight times greater than resting oxygen use in these turtles. At $30^{\circ} \mathrm{C}$ the ratio of active to standard metabolism is 20.4 in $P$. scripta and 24.3 in $T$. ornata. These values indicate an unusual ability to increase metabolism since, in general, reptiles at $30^{\circ} \mathrm{C}$ have an active to standard metabolism ratio of 5-6 (Bennett \& Dawson, 1974). It is interesting to note that in $P$. scripta oxygen consumption increases 271 -fold between rest at $10^{\circ} \mathrm{C}$ and activity at $40^{\circ} \mathrm{C}$; in $T$. ornata oxygen transport must go up a factor of 915 over this range of temperature and activity. At $37^{\circ} \mathrm{C}$, active red-eared turtles consume 95.9 and 111.0 per cent as much oxygen as resting, thermoneutral non-passerine birds (Lasiewski \& Dawson, 1967) and mammals (Kleiber, 1961), respectively, of the same body weight, whereas active ornate box turtles have corresponding values of $55 \cdot 7$ and $64 \cdot 2$ per cent.

\section{Aerobic metabolic scope}

At $30^{\circ} \mathrm{C}$ aerobic metabolic scope for activity is $0.61 \mathrm{~cm}^{3} \mathrm{O}_{2} /(\mathrm{g} \times \mathrm{hr})$, or 65 per cent of the maximum in $P$. scripta and $0.35 \mathrm{~cm}^{3} \mathrm{O}_{2} /(\mathrm{g} \times \mathrm{hr})$, or 55 per cent of the maximum in T. ornata. This parameter increases continuously from 10 to $40^{\circ} \mathrm{C}$ in both species and is always greater in red-eared turtles than in ornate box turtles. The difference is especially pronounced between 28 and $40^{\circ} \mathrm{C}$. At their common preferred body temperature of approximately $30^{\circ} \mathrm{C}$, scope for $P$. scripta is 1.75 times that of $T$. ornata. These physiological determinations coincide with observations of the behavior of these turtles in the field. Red-eared turtles are active, alert and wary animals which flee from their basking position into the water and swim rapidly to safety at any sign of movement in their environment (Cahn, 1937). While ornate box turtles may initially walk rapidly away from a predator, their common response to physical disturbance is to withdraw into the shell (Legler, 1960), an energetically inexpensive reaction which is quite effective in ensuring survival in most encounters with predators. Tucker (1967) concluded that lizards with relatively low aerobic metabolic scopes at their preferred body temperatures are slow and sluggish and do not rely on flight but employ display behavior when disturbed by a predator. On the other hand, species with relatively high scopes tend to flee rapidly when approached. This generalization appears to apply also to the turtles examined in this study.

The values for metabolic scope for turtles shown in Table 5 are all lower than values reported here, due in part to the fact that in these other studies minimal resting and maximal active conditions were not achieved. The aerobic metabolic scopes for a number of reptiles at $30^{\circ} \mathrm{C}$ are shown in Table 6 . The values are not 
TABle 6-AERobic Metabolic SCOPE $\left[\mathrm{cm}^{3} \mathrm{O}_{2} /(\mathrm{g} \times \mathrm{hr})\right]$, HeART RATE INCREMENT [beats/min] AND OXYGEN PULSE INCREMENT $\left[\mathrm{cm}^{3} \mathrm{O}_{2} \times 10^{5} /(\mathrm{g} \times\right.$ beat $\left.)\right]$ IN REPTILES AT $30^{\circ} \mathrm{C}$

\begin{tabular}{|c|c|c|c|c|c|}
\hline Species & $\begin{array}{l}\text { Body wt. } \\
\text { (g) }\end{array}$ & $\begin{array}{l}\text { Aerobic } \\
\text { metabolic } \\
\text { scope }\end{array}$ & $\begin{array}{l}\text { Heart rate } \\
\text { increment }\end{array}$ & $\begin{array}{c}\text { Oxygen } \\
\text { pulse } \\
\text { increment }\end{array}$ & Reference \\
\hline $\begin{array}{l}\text { Amphibolurus } \\
\text { barbatus }\end{array}$ & $373^{*}, 239 \dagger$ & 0.47 & $31 \downarrow$ & $9 \cdot 33$ & $\begin{array}{c}\text { Bartholomew \& } \\
\text { Tucker (1963), } \\
\text { Wilson (1971) }\end{array}$ \\
\hline $\begin{array}{l}\text { Cnemidophorus } \\
\text { tigris }\end{array}$ & 18 & 0.75 & - & - & Asplund (1970) \\
\hline $\begin{array}{l}\text { Dipsosaurus } \\
\text { dorsalis }\end{array}$ & $35 \S, 70 \|$ & 0.83 & 50 & $13 \cdot 76$ & $\begin{array}{l}\text { Licht (1965a), } \\
\text { Bennett \& Dawson } \\
(1972)\end{array}$ \\
\hline $\begin{array}{l}\text { Egernia } \\
\quad \text { cunninghami }\end{array}$ & $2647,260^{* *}$ & 0.41 & 48 & $5 \cdot 56$ & Wilson (1971) \\
\hline Iguana iguana & $369-1220++$ & $0 \cdot 31$ & 24 & $7 \cdot 23$ & Moberly (1968) \\
\hline $\begin{array}{c}\text { Physignathus } \\
\text { lesueuri }\end{array}$ & $532 ף, 585 * *$ & $0 \cdot 38$ & 48 & $5 \cdot 08$ & Wilson (1971) \\
\hline $\begin{array}{l}\text { Pituophis } \\
\text { catenifer }\end{array}$ & 548 & 0.42 & 54 & 6.55 & Greenwald (1971) \\
\hline $\begin{array}{l}\text { Pseudemys } \\
\text { scripta }\end{array}$ & 305 & 0.61 & 45 & $13 \cdot 77$ & Present study \\
\hline $\begin{array}{l}\text { Sauromalus } \\
\text { hispidus }\end{array}$ & 574 & 0.41 & 46 & $7 \cdot 69$ & Bennett (1972) \\
\hline $\begin{array}{r}\text { Sceloporus } \\
\text { graciosus }\end{array}$ & 7 & - & 80 & - & Licht (1965a) \\
\hline $\begin{array}{l}\text { Spalerosophis } \\
\text { cliffordi }\end{array}$ & $100-500+t$ & $0 \cdot 26$ & 24 & $3 \cdot 79$ & $\begin{array}{l}\text { Dmi'el \& Borut } \\
(1972)\end{array}$ \\
\hline $\begin{array}{l}\text { Sphenodon } \\
\text { punctatum }\end{array}$ & 430 & $0 \cdot 12$ & 22 & $1 \cdot 83$ & Wilson \& Lee (1970) \\
\hline $\begin{array}{l}\text { Terrapene } \\
\text { ornata }\end{array}$ & 354 & $0 \cdot 35$ & 44 & $8 \cdot 59$ & Present study \\
\hline $\begin{array}{l}\text { Tiliqua } \\
\quad \text { rugosa }\end{array}$ & $456 \pi, 424 * *$ & $0 \cdot 36$ & 53 & $4 \cdot 28$ & Wilson (1971) \\
\hline $\begin{array}{l}\text { Tiliqua } \\
\text { scincoides }\end{array}$ & 493 & $0 \cdot 16$ & 29 & $2 \cdot 38$ & $\begin{array}{l}\text { Bartholomew et al. } \\
\quad \text { (1965) }\end{array}$ \\
\hline Uma notata & 19 & - & 75 & - & Licht (1965a) \\
\hline Uta stansburiana & 4 & $0.60 \pm t$ & - & - & $\begin{array}{l}\text { Alexander \& } \\
\text { Whitford (1968) }\end{array}$ \\
\hline Varanus gouldii & 674 & 0.49 & 31 & $9 \cdot 81$ & Bennett (1972) \\
\hline Varanus spp. & 714 & 0.28 & 24 & $5 \cdot 97$ & $\begin{array}{l}\text { Bartholomew \& } \\
\text { Tucker (1964) }\end{array}$ \\
\hline
\end{tabular}

* Animals used by Bartholomew \& Tucker (1963) in determining standard metabolic rate, standard heart rate and non-maximal active heart rate.

† Animals used by Wilson (1971) in determining active metabolic rate.

I Active animals not maximally active.

$\S$ Animals used by Bennett \& Dawson (1972) in determining metabolic rates.

II Animals used by Licht (1965a) in determining heart rates.

If Resting animals.

** Active animals.

†† Range; mean weight not given.

It Estimated from data at 25 and $35^{\circ} \mathrm{C}$. 
necessarily the maximum scopes for each species since scope varies with body temperature. The scope determined here for $T$. ornata falls well within the range of scope for lizards and snakes. However, only two lizard species, Cnemidophorus tigris (Asplund, 1970) and Dipsosaurus dorsalis (Bennett \& Dawson, 1972) have a metabolic scope which exceeds that of $P$. scripta at $30^{\circ} \mathrm{C}$. Since small reptiles have greater weight-specific acrobic metabolic scopes than large ones (Bennett $\&$ Dawson, 1974), it is not surprising that these lizards with mean weights of 18 and $35 \mathrm{~g}$, respectively, have higher scopes than the 305-g red-eared turtles used in this study. Maximum aerobic scope appears to occur near the preferred body temperature in lizards (Wilson, 1971) with the exception of varanids, where scope continues to increase with body temperatures in excess of the preferred level (Bartholomew \& Tucker, 1964; Bennett, 1972). The turtles studied here seem to resemble varanids more closely than other lizards in this regard.

\section{Standard heart rate}

$P$. scripta has a standard heart rate 1.5-1.6 times that of $T$. ornata at all body temperatures from 10 to $40^{\circ} \mathrm{C}$. This difference parallels that in standard metabolic rate between these two species. Testudinian heart rates reported by other authors (Table 7) are generally two to three times greater than the values reported here,

TABle 7-Heart RATE IN TURTLES

\begin{tabular}{|c|c|c|c|c|c|}
\hline Species & $\begin{array}{l}\text { Body wt. } \\
\text { (g) }\end{array}$ & $\begin{array}{c}T_{\mathrm{b}} \\
\left({ }^{\circ} \mathrm{C}\right)\end{array}$ & beats $/ \mathrm{min}$ & $Q_{10}$ & Reference \\
\hline Caretta sp. & Not given & $22 \cdot 0$ & 45 & & Wilber (1962) \\
\hline Chelydra sp. & Not given & $22 \cdot 0$ & 35 & & Wilber (1962) \\
\hline Chelydra serpentina* & 1700 & $22 \cdot 3$ & $28 \cdot 5$ & & Kaplan \& Schwartz (1963) \\
\hline Chrysemys picta* & 394 & $25 \cdot 2$ & $22 \cdot 4$ & & Kaplan \& Schwartz (1963) \\
\hline Emys blandingii* & 1143 & $25 \cdot 7$ & $27 \cdot 2$ & & Kaplan \& Schwartz (1963) \\
\hline \multirow[t]{7}{*}{ Graptemys geographica } & Not given & 10 & 7 & & Akers \& Damm (1963) \\
\hline & & 15 & 17 & $\begin{array}{l}5 \cdot 9 \\
2.5\end{array}$ & \\
\hline & & 20 & 27 & $\begin{array}{l}2 \cdot 5 \\
2 \cdot 0\end{array}$ & \\
\hline & & 25 & 46 & $2 \cdot 9$ & \\
\hline & & 30 & $53\}$ & $1 \cdot 3$ & \\
\hline & & 35 & $72\}$ & $1 \cdot 8$ & \\
\hline & & 40 & $92\}$ & 1.6 & \\
\hline Pseudemys sp. & Not given & $20 \cdot 6$ & $17 \cdot 0$ & & Kaplan \& Taylor (1957) \\
\hline Pseudemys concinna $\dagger$ & $1800-6500$ & $22 \cdot 0$ & $20 \cdot 7$ & & Belkin (1964) \\
\hline \multirow[t]{2}{*}{ Pseudemys scripta } & 3000 & 7 & 7 & & White \& Ross (1965) \\
\hline & & 20 & 30 & & \\
\hline \multirow{4}{*}{$\begin{array}{l}\text { Pseudemys scripta } \\
\quad \text { elegans }\end{array}$} & Not given & 5 & $7 \cdot 0$ & & Rodbard et al. (1949) \\
\hline & & 15 & $20 \cdot 3$ & & \\
\hline & & 30 & $34 \cdot 0$ & & \\
\hline & & 40 & $30 \cdot 1$ & & \\
\hline $\begin{array}{l}\text { Pseudemys scripta } \\
\text { elegans* }\end{array}$ & 946 & $22 \cdot 1$ & $33 \cdot 2$ & & Kaplan \& Schwartz (1963) \\
\hline
\end{tabular}


TABLE 7 (cont.)

\begin{tabular}{|c|c|c|c|c|c|}
\hline Species & $\begin{array}{l}\text { Body wt. } \\
\quad(g)\end{array}$ & $\begin{array}{c}T_{\mathrm{b}} \\
\left({ }^{\circ} \mathrm{C}\right)\end{array}$ & beats/min & $Q_{10}$ & Reference \\
\hline $\begin{array}{l}\text { Pseudemys scripta } \\
\quad \text { elegans } \ddagger\end{array}$ & $300-800$ & $\begin{array}{l}15 \\
20 \\
25 \\
30 \\
35\end{array}$ & $\left.\begin{array}{l}16 \\
25 \\
44 \\
61 \\
71\end{array}\right\}$ & $\begin{array}{l}2 \cdot 5 \\
3 \cdot 2 \\
1 \cdot 9 \\
1 \cdot 4\end{array}$ & Hutton et al. (1960) \\
\hline $\begin{array}{l}\text { Pseudemys scripta } \\
\quad \text { elegans }\end{array}$ & Not given & $\begin{array}{l}10 \\
15 \\
20 \\
25 \\
30 \\
35\end{array}$ & $\left.\begin{array}{rr}8 & \\
17 & \\
29 & \\
42 & \\
50 & \\
70 & \}\end{array}\right\}$ & $\begin{array}{l}4 \cdot 5 \\
2 \cdot 9 \\
2 \cdot 1 \\
1 \cdot 4 \\
2 \cdot 0\end{array}$ & Akers \& Damm (1963) \\
\hline Testudo denticulato & 5000 & $\begin{array}{l}14 \\
20 \\
30\end{array}$ & $\begin{array}{c}10 \\
22 \\
31-52\end{array}$ & & Benedict (1932) \\
\hline $\begin{array}{l}\text { Terrapene sp. } \\
\text { Terrapene carolina }\end{array}$ & $\begin{array}{l}\text { Not given } \\
658\end{array}$ & $\begin{array}{l}22 \\
23 \cdot 3\end{array}$ & $\begin{array}{l}39 \\
30 \cdot 0\end{array}$ & & $\begin{array}{l}\text { Wilber (1962) } \\
\text { Kaplan \& Schwartz (1963) }\end{array}$ \\
\hline Terrapene ornata & 210 & $\begin{array}{l}30 \\
35 \\
40\end{array}$ & $\left.\begin{array}{l}54 \\
78 \\
95\end{array}\right\}$ & $\begin{array}{l}2 \cdot 1 \\
1 \cdot 5\end{array}$ & Riedesel et al. (1971) \\
\hline Terrapene ornata & $281-306$ & $30 \cdot 0$ & $30 \cdot 0$ & & Bethea (1972) \\
\hline
\end{tabular}

Values are not necessarily standard heart rate.

* Recently fed females.

+ In water, breathing air after a dive.

$\ddagger$ Values extrapolated from Fig. 2 of Hutton et al. (1960).

undoubtedly due in part to the absence of standard conditions during measurement in these studies. The influence of temperature on the cardiac rate of turtles has been recognized for many years (Lewis, 1916; Benedict, 1932). The $Q_{10}$ for standard heart rate remained constant with increasing body temperature, did not differ significantly between the two species $(1.93$ and 2.01 for red-eared and ornate box turtles, respectively), and was lower than $Q_{10}$ for standard metabolic rate in these same animals. Temperature coefficients calculated from data reported by other authors for heart rates in turtles (Table 7) tend to decrease with increasing temperature and are generally higher than those reported here between 10 and $25^{\circ} \mathrm{C}$ and lower than those reported here from 25 to $40^{\circ} \mathrm{C}$.

Bartholomew \& Tucker's (1964) equation relating standard heart rate in varanid lizards to body weight at $30^{\circ} \mathrm{C}$ predicts that a varanid the size of $P$. scripta would have a heart rate of 35.9 beats/min (rather than 20.6 beats $/ \mathrm{min}$ ) and one the size of $T$. ornata would have 35.1 beats/min (rather than 13.5 beats $/ \mathrm{min}$ ). Thus, it appears that these chelonians have standard heart rates 38-57 per cent of those of comparably sized varanid lizards at $30^{\circ} \mathrm{C}$. This difference is similar to that in standard metabolic rate between turtles and lizards. The relationship between 
body temperature and standard heart rate found in turtles and lizards appears to be similar to that in snakes (Johansen, 1959; Mullen, 1967; Jacobson \& Whitford, 1970, 1971; Vinegar et al., 1970; Aleksiuk, 1971; Greenwald, 1971; Dmi'el \& Borut, 1972), in crocodilians (Coulson \& Hernandez, 1964; Huggins et al., 1969) and in the tuatara (Wilson \& Lee, 1970; McDonald \& Heath, 1971).

\section{Active heart rate}

Cardiac frequency during maximal activity is greater in $P$. scripta than in $T$. ornata from 23 to $40^{\circ} \mathrm{C}$. No records exist in the literature for heart rates of turtles during maximal activity although many of the values listed in Table 7 fall in the range of measurements made here. This supports the idea that most of the cardiac rates summarized in the table were not recorded under standard conditions. Active heart rate changes more with increasing temperature in redeared turtles than in ornate box turtles. $P$. scripta has a $Q_{10}$ for active heart rate which decreases with increasing temperature; on the other hand, the value of this coefficient for $T$. ornata remains stable from 10 to $40^{\circ} \mathrm{C}$. Both of these patterns and similar values for $Q_{10}$ of active heart rate have been found in lizards (Dawson, 1967; Templeton, 1970).

Licht (1965a) derived an equation relating active heart rate to body weight in lizards at $30^{\circ} \mathrm{C}$. At this temperature, lizards of the same size as the turtles studied here would have active heart rates of $45-47$ beats/min in contrast to the values found here of $60-65$ beats $/ \mathrm{min}$. Other things being equal, it appears that active turtles have a higher heart rate than active lizards.

Active heart rate is always at least $2 \cdot 3$ times greater than resting heart rate in these testudinians. At $30^{\circ} \mathrm{C}$ the ratio of active to standard cardiac frequency is 3.2 in red-eared turtles and 4.3 in ornate box turtles. This ratio is lower in $P$. scripta than in $T$. ornata at any body temperature and varies between $2 \cdot 3$ and 6.8 , whereas the ratio of active to standard metabolic rate in these turtles lies between 8.0 and 29.6 over the same temperature range. These chelonians at $30^{\circ} \mathrm{C}$ have a greater active to standard heart rate ratio than any of the squamates listed in Table 6 . From rest at $10^{\circ} \mathrm{C}$ to activity at $40^{\circ} \mathrm{C}$, heart rate increases by a factor of 16.9 in $P$. scripta and 28.2 in $T$. ornata, as compared with 271 - and 915 -fold increments, respectively, for metabolic rate. Clearly, the change in heart rate cannot alone supply the additional oxygen required during activity and with increasing temperature in these reptiles.

\section{Heart rate increment}

At $30^{\circ} \mathrm{C}$ heart rate increment is 44.6 beats $/ \mathrm{min}$, or 83 per cent of the maximum value in red-eared turtles and 44.4 beats $/ \mathrm{min}$, or 67 per cent of the maximum value in ornate box turtles. Thus, virtually no difference exists between these turtles in the degree to which heart rate can be elevated during activity at their preferred body temperature. The increase in heart rate increment with rising temperature is substantially less than the corresponding increase in metabolic scope. In both species, heart rate increment continues to rise with increasing body temperature, 
as does metabolic scope, with maximum values for both parameters occurring at $40^{\circ} \mathrm{C}$. This parameter in $P$. scripta and $T$. ornata at $30^{\circ} \mathrm{C}$ falls within the range of measurements for other reptiles (Table 6). The values shown in the table do not necessarily represent the maximum heart rate increment for each species, since this increment varies with temperature and generally occurs near the preferred body temperature. However, some lizards, like the turtles studied here, have heart rate increments which increase continuously with increasing body temperature (Bartholomew \& Tucker, 1964; Moberly, 1968; Bennett, 1972). Coincidence at

TABle 8-Preferred body temperature, temperature for maXimal aERobic Metabolic SCOPE, AND TEMPERATURE FOR MAXIMAL HEART RATE INCREMENT IN REPTILES

\begin{tabular}{|c|c|c|c|}
\hline Species & $T_{\left.\text {pref }{ }^{\circ} \mathrm{C}\right)}$ & $T_{\max \text { scope }\left({ }^{\circ} \mathrm{C}\right)}$ & $T_{\max \text { HRI }\left({ }^{\circ} \mathrm{C}\right)}$ \\
\hline Amphibolurus barbatus & $35 \cdot 7 *$ & $35 \dagger$ & $25 \ddagger$ \\
\hline Cnemidophorus tigris & $40 \cdot 4 \S, \|$ & $40 \pi$ & NA \\
\hline Dipsosaurus dorsalis & $38 \cdot 8^{* *}$ & $40+\dagger$ & $42 * *$ \\
\hline Egernia cunninghami & $32 \cdot 5 \uparrow$ & $35 \dagger$ & $36+$ \\
\hline Iguana iguana & $\begin{array}{l}33 \cdot 4 \pm \ddagger \\
36.2 \S \S\end{array}$ & $33 \S \S$ & $43 \S \S$ \\
\hline Physignathus lesueuri & $30 \cdot 1 \dagger$ & $30 \dagger$ & $32 \dagger$ \\
\hline Pituophis catenifer & $\begin{array}{l}26.7 \mid \| 11 \\
30.0 \dagger\end{array}$ & 30\|\| & 30\|\| \\
\hline Pseudemys scripta & $29 \cdot 11 \pi$ & $40^{* * *}$ & $40^{* * *}$ \\
\hline Sauromalus hispidus & $37 \cdot 1+t \dagger$ & $38+t+$ & $40+t+$ \\
\hline Sceloporus graciosus & $35 \cdot 3^{* *}$ & $\mathrm{NA}$ & $37^{* *}$ \\
\hline Spalerosophis cliffordi & $29 \cdot 9 \ddagger \ddagger \ddagger$ & $35 \ddagger \ddagger \ddagger$ & $30 \ddagger t$ \\
\hline Sphenodon punctatum & $\begin{array}{l}18-19 \S \S \S \\
25 \cdot 0 \dagger\end{array}$ & $25 \S \S \S$ & $25 \S \S \S$ \\
\hline Terrapene ornata & $29 \cdot 8 \pi \uparrow$ & $40 * * *$ & $40^{* * *}$ \\
\hline Tiliqua rugosa & $\begin{array}{l}33.9 * * \\
32.6+\end{array}$ & $33 \dagger$ & $\begin{array}{l}35 * * \\
34+\end{array}$ \\
\hline Tiliqua scincoides & 32.6\|\|$\|\|$, & 40\|\|\|\| & 30\|\|\|\| \\
\hline Uma notata & $37 \cdot 5^{* *}$ & $\mathrm{NA}$ & $39 * *$ \\
\hline Uta stansburiana & $35 \cdot 4 \S, \|$ & 35ग शा & NA \\
\hline Varanus gouldii & $37 \cdot 5 * * * *$, & $40+t t$ & $40+\uparrow \dagger$ \\
\hline Varanus spp. & $35 \cdot 5 * * * *$, & $40^{* * * *}$ & $40^{* * * *}$ \\
\hline
\end{tabular}

Modified in part from Wilson (1971).

* Licht et al. (1966). +Wilson (1971).

$\ddagger$ Bartholomew \& Tucker (1963). Active animals not maximally active.

$\S$ Brattstrom (1965).

1/ Mean body temperature of animals active in nature, not preferred body temperature in a thermal gradient.

T Asplund (1970). ** Licht 1965a. + Bennett \& Dawson (1972). † McGinnis \& Brown (1966). \$\$Moberly (1968). III Greenwald (1971). II Gatten (1974). *** Present study. †† Bennett (1972). †† Dmi'el \& Borut (1972). $\S \S \S W i l s o n$ \& Lee (1970). II/l|| Bartholomew et al. (1965). TाT Alexander \& Whitford (1968). **** Bartholomew \& Tucker (1964). NA, Not available. 
the same body temperature of maximal metabolic scope and maximal heart rate increment have been found in reptiles other than the turtles studied here (Bartholomew \& Tucker, 1964; Licht, 1965a; Wilson \& Lee, 1970; Greenwald, 1971; Wilson, 1971; Bennett, 1972; Bennett \& Dawson, 1972). Table 8 summarizes the available information on preferred body temperature, temperature for maximal aerobic metabolic scope and tempcrature for maximal hcart rate increment in reptiles. Exact overlap of these temperatures would appear to optimize the provision of energy for animals active in nature, but this situation rarely occurs, perhaps because of the thermal requirements of other physiological systems (Licht, 1964a, b, 1965a, b; Dawson, 1967; Licht et al., 1969; Dawson, 1971).

\section{Standard oxygen pulse}

Since standard metabolic rate and standard heart rate do not change in a commensurate manner with increasing body temperature in P. scripta and $T$. ornata, their standard oxygen pulse will not remain constant over the same temperature range. Resting red-eared turtles are generally less reliant than ornate box turtles on increasing oxygen transport by an increase in oxygen pulse during a rise in body temperature. Among reptiles, standard oxygen pulse may increase, decrease or remain constant with changing body temperature within a species but it is remarkably uniform in reptiles as a group at $30^{\circ} \mathrm{C}$, generally varying from $2 \cdot 0 \times 10^{-5}$ to $5 \cdot 0 \times 10^{-5} \mathrm{~cm}^{3} \mathrm{O}_{2} /(\mathrm{g} \times$ beat) in lizards (Dawson, 1967 ; Templeton, 1970; Wilson, 1971; Bennett, 1972), and in snakes (Jacobson \& Whitford, 1970, 1971; Vinegar et al., 1970; Greenwald, 1971; Dmi'el \& Borut, 1972), but being only approximately $1.0 \times 10^{-5} \mathrm{~cm}^{3} \mathrm{O}_{2} /(\mathrm{g} \times$ beat) in the tuatara (Wilson \& Lee, 1970). The values for standard oxygen pulse at $30^{\circ} \mathrm{C}, 2.54 \times 10^{-5}$ and $1.85 \times$ $10^{-5} \mathrm{~cm}^{3} \mathrm{O}_{2} /(\mathrm{g} \times$ beat $)$ in $P$. scripta and $T$. ornata, respectively, thus fall within the lower range of measurements for other reptiles.

The only study in resting reptiles of the effect of change in body temperature on the simultaneous alteration in oxygen consumption, heart rate, stroke volume and arterial-venous oxygen difference was that by Tucker (1966) on Iguana iguana. From 20 to $38^{\circ} \mathrm{C}$, the 4.4 -fold increase in oxygen consumption was met by a $4 \cdot 1$-fold increase in heart rate, a 50 per cent decrease in stroke volume and a 2 -2-fold increase in $A-V$ difference. In the present study, red-eared turtles resting between 20 and $30^{\circ} \mathrm{C}$ increased oxygen consumption and heart rate by factors of 2.9 and 1.9 , respectively. Similarly, from 20 to $30^{\circ} \mathrm{C}$, standard metabolic rate increased by a factor of 1.6 and standard heart rate rose twofold in ornate box turtles. Thus, the product of stroke volume and $A-V$ difference would not remain as constant in these species from 20 to $30^{\circ} \mathrm{C}$ as it did in the iguana from 20 to $38^{\circ} \mathrm{C}$.

\section{Active oxygen pulse}

Oxygen pulse during activity is greater in $P$. scripta than in $T$. ornata, especially at body temperatures below $20^{\circ} \mathrm{C}$, but increases relatively more with increase in 
body temperature in ornate box turtles than in red-eared turtles. The latter species appears to depend less than the former on change in stroke volume and/or oxygen extraction efficiency to supply increased energy needs with rising temperature. Active oxygen pulse at $30^{\circ} \mathrm{C}$ has been shown to fall between $5 \times 10^{-5}$ and $16 \times$ $10^{-5} \mathrm{~cm}^{3} \mathrm{O}_{2} /(\mathrm{g} \times$ beat) in lizards (Bartholomew \& Tucker, 1963, 1964; Bartholomew et al., 1965; Licht, 1965a; Moberly, 1968; Wilson, 1971; Bennett, 1972; Bennett \& Dawson, 1972), and between $7 \times 10^{-5}$ and $9 \times 10^{-5} \mathrm{~cm}^{3} \mathrm{O}_{2} /(\mathrm{g} \times$ beat $)$ in snakes (Greenwald, 1971; Dmi'el \& Borut, 1972). It is approximately $3 \times 10^{-5} \mathrm{~cm}^{3}$ $\mathrm{O}_{2} /(\mathrm{g} \times$ beat) in the tuatara (Wilson \& Lee, 1970). The value determined here for active oxygen pulse in $P$. scripta at $30^{\circ} \mathrm{C}, 16.31 \times 10^{-5} \mathrm{~cm}^{3} \mathrm{O}_{2} /(\mathrm{g} \times$ beat $)$, is thus greater than for any reptile studied previously. T. ornata at $30^{\circ} \mathrm{C}$ have an active oxygen pulse of $10.44 \times 10^{-5} \mathrm{~cm}^{3} \mathrm{O}_{2} /(\mathrm{g} \times$ beat $)$, which falls well within the range of values for other reptiles. The fact that this parameter increases continuously with increasing body temperature in these turtles during activity, as is the case in varanid lizards (Bartholomew \& Tucker, 1964; Bennett, 1972) indicates they are less reliant than most other reptiles (Bartholomew \& Tucker, 1963; Bartholomew et al., 1965; Wilson \& Lee, 1970; Dmi'el \& Borut, 1972) on increase in heart rate to supply extra oxygen transport as their body temperature rises.

The only study to assess the relative contribution of heart rate, stroke volume and arterial-venous oxygen difference to added oxygen consumption during activity in a reptile was that of Tucker (1966), who used only two specimens of I. iguana. During activity, heart rate and $A-V$ difference increased at all temperatures but stroke volume decreased in one animal and increased in the other. In red-eared turtles at $30^{\circ} \mathrm{C}$, oxygen consumption increased by a factor of 20.4 during activity while heart rate rose $3 \cdot 2$ times. Therefore, the product of stroke volume and arterial-venous difference must have increased by a factor of 6.4 . Under similar circumstances oxygen utilization increased $24 \cdot 3$ times and heart rate went up 4.3 times in ornate box turtles, indicating that oxygen pulse rose by a factor of 5.6. The relative contribution of stroke volume and the extraction coefficient to these oxygen pulse values in these animals must await further study.

\section{Oxygen pulse increment}

Oxygen pulse increment quantifies the absolute change in the product of stroke volume and arterial-venous oxygen difference during exercise. This parameter is consistently greater in $P$. scripta than in $T$. ornata which indicates that the former relies less on heart rate increment to supply the increased quantity of oxygen needed during activity than does the latter species. Oxygen pulse increment at $30^{\circ} \mathrm{C}$ is greater in red-eared turtles than in any reptile studied previously (Table 6). Only D. dorsalis (Bennett \& Dawson, 1972) and $V$. gouldii (Bennett, 1972), both highly active, thermophilic species, surpass ornate box turtles in this increment at $30^{\circ} \mathrm{C}$. From this comparison it is clear that $P$. scripta and $T$. ornata rely to an important extent on change in stroke volume and/or extraction of oxygen from the blood for increased oxygen transport during activity. 


\section{Total body lactate concentration and anaerobic metabolic scope}

Blood lactate concentration is a direct consequence of the production of lactate by the muscles during anaerobic activity, its rate of diffusion into the blood and the rate of its removal from the blood by the liver. The common practice of estimating anaerobic energy utilization from blood lactate levels is unwarranted since blood is only one compartment involved in lactate distribution, and equilibrium between it and the other compartments is not always present. Blood lactate may not rise to maximal levels until minutes or hours after cessation of diving or activity in reptiles (Berkson, 1966; Moberly, 1968; Wilson, 1971; Bennett \& Licht, 1972). Therefore, in this study total body lactate concentration ('Table 3 ) was used in the calculation of anaerobic scope for activity, the difference between pre- and postexercise lactate content of the body. During $2 \mathrm{~min}$ of maximal activity the anaerobic metabolic scope at $30^{\circ} \mathrm{C}$ is $0.28 \mathrm{mg}$ lactate $/(\mathrm{g} \times \mathrm{min})$ in $P$. scripta and $0.30 \mathrm{mg}$ lactate $/(\mathrm{g} \times \mathrm{min})$ in $T$. ornata. This difference is probably not biologically important. Anaerobic scope at $40^{\circ} \mathrm{C}$, however, is zero for red-eared turtles and $0.23 \mathrm{mg}$ lactate $/(\mathrm{g} \times \mathrm{min})$ for ornate box turtles. Thus, it appears that anaerobiosis fails to liberate extra energy during activity at $40^{\circ} \mathrm{C}$ in $P$. scripta; however, anaerobic scope in $T$. ornata at $40^{\circ} \mathrm{C}$ is 76 per cent of the amount at $30^{\circ} \mathrm{C}$.

Total body lactate concentration in small lizards at rest is similar to that in these turtles but total body lactate level during activity and anaerobic scope are greater in these lizards than in P. scripta and T. ornata (Bennett \& Dawson, 1972; Bennett $\&$ Licht, 1972). This may reflect differences in body size and the relative percentage of muscle in the bodies of these reptiles. If weight-specific anaerobic scope is greater in small reptiles than in large reptiles, as is the case with weight-specific aerobic scope (see Table 6, and Bennett \& Dawson, 1974), then these turtles may have unusually large anaerobic scopes compared to similar-sized lizards. Confirmation of this idea must await further study on a large size range of reptiles.

\section{Total metabolic scope}

Since both the aerobic and the anaerobic scope for these turtles were determined in this study at 30 and $40^{\circ} \mathrm{C}$, the total amount of energy available to them during activity can be calculated. Bennett $\&$ Dawson (1972) present the proper equations relating aerobic and anaerobic metabolism to the amount of ATP generated:

$$
\begin{aligned}
1.0 \mathrm{~cm}^{3} \mathrm{O}_{2} \text { (STP) consumed } & =0.290 \mathrm{~m} \text {-moles ATP generated } \\
1.0 \mathrm{mg} \text { lactate formed } & =0.0167 \mathrm{~m} \text {-moles ATP generated }
\end{aligned}
$$

Table 9 summarizes the aerobic, anaerobic and total scope for $P$. scripta and T. ornata at 30 and $40^{\circ} \mathrm{C}$. At $30^{\circ} \mathrm{C}$ glycolysis provides 61 and 75 per cent of the total scope in red-eared and ornate box turtles, respectively, during $2 \mathrm{~min}$ of forced activity. However, at $40^{\circ} \mathrm{C}$ anaerobiosis does not contribute to the total energy available during exercise in $P$. scripta and supplies only 55 per cent of the total scope in $T$. ornata. Therefore, the preferred body temperature of $30^{\circ} \mathrm{C}$ is optimal with regard to the amount of total scope that is provided by glycolysis. 
Table 9-Aerobic, anaerobic and total scope in $P$, scripta and $T$, ornata at 30 and $40^{\circ} \mathrm{C}$ DURING $2 \mathrm{~min}$ OF MAXIMUM ACTIVITY

\begin{tabular}{lccr}
\hline Species, $T_{\mathrm{b}}\left({ }^{\circ} \mathrm{C}\right)$ & $\begin{array}{c}\text { Aerobic } \\
\text { scope }\end{array}$ & $\begin{array}{c}\text { Anaerobic } \\
\text { scope }\end{array}$ & $\begin{array}{r}\text { Total } \\
\text { scope }\end{array}$ \\
\hline P. scripta, $30^{\circ} \mathrm{C}$ & 5.87 & 9.19 & 15.06 \\
P. scripta, $40^{\circ} \mathrm{C}$ & 9.07 & 0.00 & 9.07 \\
T. ornata, $30^{\circ} \mathrm{C}$ & 3.36 & 9.85 & 13.21 \\
T. ornata, $40^{\circ} \mathrm{C}$ & 6.19 & 7.52 & 13.71 \\
\hline
\end{tabular}

All values are in m-moles of $\mathrm{ATP} \times 10^{3}$ per $\mathrm{g}$ of body weight.

Ornate box turtles rely more on anaerobiosis to provide energy for activity at both temperatures than do red-eared turtles. Anaerobiosis also provides a major portion of the energy available to lizards during activity (Moberly, 1968; Bennett \& Dawson, 1972; Bennett \& Licht, 1972).

It is significant that total scope is greater at the preferred body temperature of $30^{\circ} \mathrm{C}$ than $40^{\circ} \mathrm{C}$ in $P$. scripta. Since total scope is virtually temperature independent between 30 and $40^{\circ} \mathrm{C}$ in $T$. ornata, the former temperature is optimal for activity since the maintenance costs, i.e. standard metabolic rate, are less at this temperature than at the latter. Thus, in general, the total energy available for activity is greater at the preferred body temperature of $30^{\circ} \mathrm{C}$ than at $40^{\circ} \mathrm{C}$, even though aerobic scope, heart rate increment and oxygen pulse increment are greater at the latter temperature. Total scope is 1.14 times greater in $P$. scripta than in $T$. ornata at $30^{\circ} \mathrm{C}$. The relatively large aerobic scope and concomitant oxygen transport capabilities in these chelonians are undoubtedly of great importance in the repayment of the large oxygen debt incurred during periods of strenuous activity. It is clear that the remarkable glycolytic abilities of turtles (Belkin, 1961; Daw et al., 1967; Belkin, 1968b; Miller \& Hale, 1968; Altman \& Robin, 1969; McNeill et al., 1971; Clark \& Miller, 1973), formerly regarded as adaptations to diving hypoxia, are also significant in the energy metabolism of these animals during periods of activity.

\section{SUMMARY}

Aerobic metabolic scope is significantly greater in the active, aquatic, red-eared turtle, Pseudemys scripta, than in the more sluggish, terrestrial, ornate box turtle, Terrapene ornata. Maximum values for metabolic rates, heart rates and oxygen pulse occur at $40^{\circ} \mathrm{C}$ rather than at the preferred body temperature of $30^{\circ} \mathrm{C}$. Standard metabolic and heart rates in these turtles are lower than those reported by other authors for reptiles of the same size at the same body temperature, due in part to the absence of truly minimal, standard conditions in these other studies. An increase in heart rate alone is not sufficient to supply the increased oxygen needs during warming and exercise; therefore, the product of stroke volume and arterial-venous oxygen difference must also increase substantially. At $30^{\circ} \mathrm{C}$, the 
mean body temperature for these turtles during activity in nature, glycolysis supplies $60-75$ per cent of the energy available during a burst of activity. At this temperature total metabolic scope for activity is greater in $P$. scripta than in $T$. ornata.

Acknowledgements-This paper is a portion of a dissertation submitted in partial fulfillment of the requirements for the degree of Doctor of Philosophy in Zoology in The University of Michigan. The work was completed under the supervision of Dr. William R. Dawson, who generously provided me with access to his laboratory and equipment. Drs. Carl Gans, Karl F. Guthe and Conrad S. Yocum offered helpful suggestions and provided constructive comments during this study and during the preparation of this paper. I am grateful to the Department of Zoology of the University of Michigan for providing financial assistance, facilities and equipment. I thank Janet Cooper for typing the manuscript.

\section{REFERENCES}

AKERS T. K. \& DAMM M. G. (1963) The effect of temperature on the electrocardiograms of two species of turtles. Copeia 1963, 629-634.

ALEKSIUK M. (1971) Temperature-dependent shifts in the metabolism of a cool temperate reptile, Thamnophis sirtalis parietalis. Comp. Biochem. Physiol. 39A, 495-503.

Alexander C. E. \& Whitford W. G. (1968) Energy requirements of Uta stansburiana. Copeia 1968, 678-683.

AltMan M. \& RoBin E. D. (1969) Survival during prolonged anaerobiosis as a function of an unusual adaptation involving lactate dehydrogenase subunits. Comp. Biochem. Physiol. 30, 1179-1187.

Asplund K. K. (1970) Metabolic scope and body temperatures of whiptail lizards (Cnemidophorus). Herpetologica 26, 403-411.

BaLDwin F. M. (1926a) Some observations concerning metabolic rate in turtles, Chrysemys marginata belli and Chelydra serpentina (Linn.). Am. F. Physiol. 76, 196.

BALDwiN F. M. (1926b) Notes on oxygen consumption in turtles, Chrysemys marginata belli and Chelydra serpentina Linn. Proc. Iowa Acad. Sci. 33, 315-323.

Bartholomew G. A. \& Tucker V. A. (1963) Control of changes in body temperature, metabolism, and circulation by the agamid lizard, Amphibolurus barbatus. Physiol. Zoöl. 36, 199-218.

BARTHOLOMEW G. A. \& TUCKER V. A. (1964) Size, body temperature, thermal conductance, oxygen consumption, and heart rate in Australian varanid lizards. Physiol. Zoöl. 37, 341-354.

Bartholomew G. A., Tucker V. A. \& Lee A. K. (1965) Oxygen consumption, thermal conductance, and heart rate in the Australian skink, Tiliqua scincoides. Copeia 1965, 169-173.

BELKIN D. A. (1961) Anaerobic mechanisms in the diving of the loggerhead musk turtle, Sternothaerus minor. Ph.D. dissertation, University of Florida.

BELKIN D. A. (1964) Variations in heart rate during voluntary diving in the turtle Pseudemys concinna. Copeia 1964, 321-330.

BeLKIN D. A. (1965) Reduction of metabolic rate in rcsponse to starvation in the turtle Sternothaerus minor. Copeia 1965, 367-368.

BeLKIN D. A. (1968a) Aquatic respiration and underwater survival of two freshwater turtle species. Respir. Physiol. 4, 1-14.

BeLKIN D. A. (1968b) Anaerobic brain function: effects of stagnant and anoxic anoxia on persistence of breathing in reptiles. Science, Wash. 162, 1017-1018.

Benedict F. G. (1932) The Physiology of Large Reptiles with Special Reference to the Heat Production of Snakes, Tortoises, Lizards, and Alligators. Publication No. 425, Carnegie Institution of Washington, Washington, D.C. 
BennetT A. F. (1972) The effect of activity on oxygen consumption, oxygen debt, and heart rate in the lizards Varanus gouldii and Sauromalus hispidus. F. comp. Physiol. 79, 259-280.

Bennett A. F. \& Dawson W. R. (1971) Oxygen consumption. Reptiles. In Respiration and Circulation (Edited by Altman P. L. \& Dittmer D. S.), pp. 472-481. Fedn. Amer. Soc. Exp. Biol., Bethesda, Md.

Bennetr A. F. \& Dawson W. R. (1972) Aerobic and anaerobic metabolism during activity in the lizard Dipsosaurus dorsalis. F. comp. Physiol. 81, 289-299.

Bennett A. F. \& Dawson W. R. (1974) Metabolism. In Biology of the Reptilia (Edited by Gans C.), Vol. 5, Physiology A. Academic Press, New York. (In press.)

BenNetT A. F. \& Licht P. (1972) Anaerobic metabolism during activity in lizards. \%. comp. Physiol. 81, 277-288.

Berkson H. (1966) Physiological adjustments to prolonged diving in the Pacific green turtle (Chelonia mydas agassizii). Comp. Biochem. Physiol. 18, 101-119.

BETHEA N. J. (1972) Effects of temperature on heart rate and rates of cooling and warming in Terrapene ornata. Comp. Biochem. Physiol. 41A, 301-305.

Boyer D. R. (1965) Ecology of the basking habit in turtles. Ecology 46, 99-118.

Brattstrom B. H. (1965) Body temperatures of reptiles. Am. Midl. Nat. 73, 376-422.

Brett W. J. (1971) Persistent rhythms of locomotion activity in the turtle Pseudemys scripta. Comp. Biochem. Physiol. 40A, 925-934.

Buikema A. L., Jr. \& Armitage K. B. (1969) The effect of temperature on the metabolism of the prairie ringneck snake, Diadophis punctatus arnyi Kennicott. Herpetologica 25, 194-206.

Cagle F. R. (1946) The growth of the slider turtle, Pseudemys scripta elegans. Am. Midl. Nat. 36, 685-729.

Cahn A. R. (1937) The turtles of Illinois. Ill. Biol. Monogr. 16, 1-218.

Clatr V. M. \& Miller A. T., Jr. (1973) Studies on anaerobic metabolism in the freshwater turtle (Pseudemys scripta elegans). Comp. Biochem. Physiol. 44A, 55-62.

Coulson R. A. \& Hernandez T. (1964) Biochemistry of the Alligator: A Study of Metabolism in Slow Motion. Louisiana State University Press, Baton Rouge.

Daw J. C., Wenger D. P. \& Berne R. M. (1967) Relationship between cardiac glycogen and tolerance to anoxia in the Western painted turtle, Chrysemys picta belli. Comp. Biochem. Physiol. 22, 69-73.

Dawson W. R. (1967) Interspecific variation in physiological responses of lizards to temperature. In Lizard Ecology: A Symposium (Edited by Milstead W. W.), pp. 230257. University of Missouri Press, Columbia.

Dawson W. R. (1971) Reptiles as research models in comparative physiology. F. Am. vet. Med. Assoc. 159, 1653-1661.

Dawson W. R. \& Bartholomew G. A. (1956) Relation of oxygen consumption to body weight, temperature, and temperature acclimation in lizards Uta stansburiana and Sceloporus occidentalis. Physiol. Zoöl. 29, 40-51.

Depocas F. \& HarT J. S. (1957) Use of the Pauling oxygen analyzer for measurement of oxygen consumption of animals in open-circuit systems and in a short-lag, closedcircuit apparatus. F. appl. Physiol. 10, 388-392.

DMi'El R. \& Borut A. (1972) Thermal behavior, heat exchange, and metabolism in the desert snake Spalerosophis cliffordi. Physiol. Zoöl. 45, 78-94.

FRY F. E. J. (1947) Effects of the environment on animal activity. Pub. Ont. Fish. Res. Lab. 68, $1-62$.

Gans C. \& Hughes G. M. (1967) The mechanism of lung ventilation in the tortoise Testudo graeca Linne. F. exp. Biol. 47, 1-20.

GatTen R. E., JR. (1974a) Effect of nutritional status on the preferred body temperature of the turtles Pseudemys scripta and Terrapene ornata. Copeia (In press.) 
Gatten R. E., JR. (1974b) Percentage contribution of increased heart rate to increased oxygen transport during activity in Pseudemys scripta, Terrapene ornata and other reptiles. Comp. Biochem. Physiol. 48A, 649-652.

Gaunt A. S. \& Gans C. (1969) Mechanics of respiration in the snapping turtle, Chelydra serpentina (Linne). F. Morph. 128, 195-228.

GreENwald O. E. (1971) The effect of body temperature on oxygen consumption and heart rate in the Sonora gopher snake, Pituophis catenifer affinis Hallowell. Copeia 1971, 98-106.

Huggins S. E., Hoff H. E. \& Pena R. V. (1969) Heart and respiratory rates in crocodilian reptiles under conditions of minimal stimulation. Physiol. Zoöl. 42, 320-333.

Hughes G. M., Gaymer R., Moore M. \& Woakes A. J. (1971) Respiratory exchange and body size in the Aldabra giant tortoise. F. exp. Biol. 55, 651-665.

Hutton K. E., Boyer D. R., Williams J. C. \& Campbell P. M. (1960) Effects of temperature and body size upon heart rate and oxygen consumption in turtles. $\mathcal{J}$. cell. comp. Physiol. 55, 87-94.

JACOBSON E. R. \& Whitford W. G. (1970) The effect of acclimation on physiological responses to temperature in the snakes, Thamnophis proximus and Natrix rhombifera. Comp. Biochem. Physiol. 35, 439-449.

Jacosson E. R. \& Whitfond W. G. (1971) Physiological responses to temperature in the patch-nosed snake, Salvadora hexalepis. Herpetologica 27, 289-295.

JoHANSEN K. (1959) The influence of temperature on the electrocardiograms of some northern reptiles. Acta Physiol. Scand. 46, 346-357.

Kaplan H. M. \& Schwartz C. (1963) Electrocardiography in turtles. Life Sci. 2, 637-645.

Kaplan H. M. \& Taylor R. (1957) Anesthesia in turtles. Herpetologica 13, 43-45.

KLeIber M. (1961) The Fire of Life. Wiley, New York.

LAsiEwski R. C. \& DAwson W. R. (1967) A re-examination of the relation between standard metabolic rate and body weight in birds. Condor 69, 13-23.

LEGLER J. M. (1960) Natural history of the ornate box turtle, Terrapene ornata ornata Agassiz. Univ. Kan. Publ., Mus. Nat. Hist. 11, 527-669.

LEwIS T. (1916) The spread of the excitatory process in the vertebrate heart. Phil. Trans. R. Soc. Lond. B 207, 221-310.

Licht P. (1964a) The temperature dependence of myosin-adenosinetriphosphatase and alkaline phosphatase in lizards. Comp. Biochem. Physiol. 12, 331-340.

Licht P. (1964b) A comparative study of the thermal dependence of contractility in saurian skeletal muscle. Comp. Biochem. Physiol. 13, 27-34.

LICHT P. (1965a) Effects of temperature on heart rates of lizards during rest and activity. Physiol. Zoöl. 38, 129-137.

LicHT P. (1965b) The relation between preferred body tcmperaturc and testicular heat sensitivity in lizards. Copeia 1965, 428-436.

Licht P., Dawson W. R. \& Shoemaker V. H. (1969) Thermal adjustments in cardiac and skeletal muscles of lizards. Z. vergl. Physiol. 65, 1-14.

Licht P., Dawson W. R., Shoemaker V. H. \& Main A. R. (1966) Observations on the thermal relations of Western Australian lizards. Copeia 1966, 97-110.

McCutcheon F. H. (1943) The respiratory mechanism in turtles. Physiol. Zoöl. 16, 255269.

McDonald H. S. \& Heath J. E. (1971) Electrocardiographic observations on the tuatara, Sphenodon punctatus. Comp. Biochem. Physiol. 40A, 881-892.

McGinnis S. M. \& Brown C. W. (1966) Thermal behavior of the green iguana, Iguana iguana. Herpetologica 22, 189-199.

McNeill J. H., Davis R. S. \& LaRochelle D. (1971) Glycogen phosphorylase levels in spontaneously beating turtle hearts. Comp. Biochem. Physiol. 39B, 689-693.

Miller A. T. \& Hale D. M. (1968) Comparisons of lactic dehydrogenase in rat and turtle organs. Comp. Biochem. Physiol. 27, 597-601. 
Moberly W. R. (1968) The metabolic responses of the common iguana, Iguana iguana, to activity under restraint. Comp. Biochem. Physiol. 27, 1-20.

Mullen R. K. (1967) Comparative electrocardiography of the squamata. Physiol. Zoöl. 40, 114-126.

Riedesel M. L., Cloudsley-Thompson J. L. \& Cloudsley-Thompson J. A. (1971) Evaporative thermoregulation in turtles. Physiol. Zoöl. 44, 28-32.

RoBERTS L. A. (1968) Oxygen consumption in the lizard Uta stansburiana. Ecology 49, 809-819.

Rodbard S., Tinsley M., Bornstein H. \& Taylor L. (1949) Role of the central nervous system in the body temperature-arterial pressure relationship. Am. . Physiol. 158, $135-140$.

Root R. W. (1949) Aquatic respiration in the musk turtle. Physiol. Zoöl. 22, 172-178.

SPRAY D. C. \& MAY M. L. (1972) Heating and cooling rates in four species of turtles. Comp. Biochem. Physiol. 41A, 507-522.

Templeton J. R. (1970) Reptiles. In Comparative Physiology of Thermoregulation (Edited by Whitrow G. C.), Vol. 1, pp. 167-221. Academic Press, New York.

Tucker V. A. (1966) Oxygen transport by the circulatory system of the green iguana (Iguana iguana) at different body temperatures. \%. exp. Biol. 44, 77-92.

Tucker V. A. (1967) The role of the cardiovascular system in oxygen transport and thermoregulation in lizards. In Lizard Ecology: $A$ Symposium (Edited by Milstead W. W.), pp. 258-269. University of Missouri Press, Columbia.

Vinegar A., Hutchison V.H. \& Dowling H. G. (1970) Metabolism, energetics, and thermoregulation during brooding of snakes of the genus Python (Reptilia, Boidae). Zoologica $55,19-48$.

WebB G. J. W. \& Johnson C. R. (1972) Head-body temperature differences in turtles. Comp. Biochem. Physiol. 43A, 593-611.

White F. N. \& Ross G. (1965) Blood flow in turtles. Nature, Lond. 208, 759-760.

WILBER C. G. (1962) Some circulatory problems in reptiles and amphibians. Ohio $\mathcal{F}$. Sci. 62, 132-138.

WILsoN K. J. (1971) The relationships of activity, energy, metabolism, and body temperature in four species of lizards. Ph.D. dissertation, Monash University, Australia.

WILSON K. J. \& LEE A. K. (1970) Changes in oxygen consumption and heart-rate with activity and body temperature in the tuatara, Sphenodon punctatum. Comp. Biochem. Physiol. 33, 311-322.

Key Word Index-Aerobic metabolism; anaerobic metabolism; metabolic rate; oxygen consumption; heart rate; oxygen pulse; oxygen transport; activity; temperature; anaerobiosis; glycolysis; lactate; turtle; Pseudemys scripta; Terrapene ornata. 